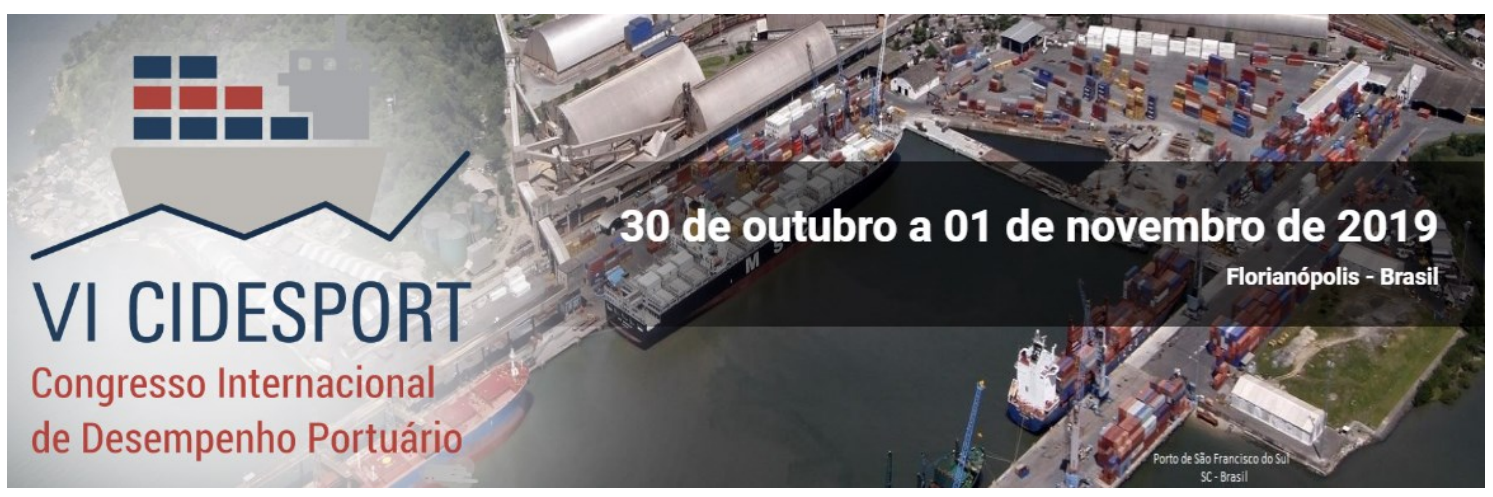

\title{
CABOTAGEM BRASILEIRA: MAPEAMENTO DA ORIGEM E DESTINO DAS CARGAS - DIAGNÓSTICO E PERSPECTIVAS DE CRESCIMENTO
}

\section{Alexandre Sandre Martins \\ Banco Nacional de Desenvolvimento Econômico e Social}

Resumo: A cabotagem tem potencial para contribuir na redução dos custos de transporte de diversas cadeias de suprimentos, com reflexos positivos na competividade das empresas brasileiras e melhora na qualidade de vida da população através da redução das emissões de $\mathrm{CO} 2$, diminuição dos acidentes rodoviários e dos preços praticados ao consumidor final, como reflexo do seu menor custo unitário do frete. A cabotagem brasileira é concentrada no transporte de granéis, representando em torno de $91 \%$ do total transportado no ano de 2018, com destaque para os granéis líquidos, representando $73 \%$ desse total. Nesse setor podemos caracterizar três mercados sob o ponto de vista econômico: o mercado de granéis líquidos, que abrange de forma preponderante as operações logísticas da Petrobras, modalidade Industrial Operation; o mercado de granéis sólidos, voltado ao escoamento das demais commodities, com foco em volume; e o mercado de carga geral e contêineres, com foco principal em longas distâncias na costa brasileira, cujo mercado é distinto dos demais, apesar dos três mercados serem definidos legalmente como cabotagem. O presente artigo apresenta um panorama deste modal no Brasil, a partir da ótica de origem e destino das cargas transportadas pela cabotagem e propõe, a partir da estimativa do transporte rodoviário de carga geral de longa distância, um potencial de substituição deste modal para o mercado de cabotagem de carga geral e contêiner. Conclui-se com um diagnóstico da situação atual, uma estimativa do crescimento potencial da cabotagem de carga geral e contêiner, além da proposição do aprofundamento do presente estudo, para uma maior inserção da cabotagem, objetivando uma matriz de transportes mais equilibrada entre os diferentes modais que a compõe.

Palavras-chave: Cabotagem. Origem. Destino. Substituição. Equilíbrio.

\section{CONTEXTUALIZAÇÃO}

No Brasil, até a década de 1930 , a Cabotagem era o principal modal para transportes de cargas no país, favorecido pela sua configuração geográfica, com aproximadamente 7.408 (sete mil quatrocentos e oito) mil km de costa, 8 (oito) mil incluindo vias interiores até Manaus, bem como pela forma como ocorreu a ocupação do seu território desde o período colonial, acarretando a concentração de aproximadamente $80 \%$ da população numa faixa de até $200 \mathrm{~km}$ do litoral, vocacionando a cabotagem como o meio mais eficiente para o transporte das mercadorias em fluxos inter-regionais, para atendimento de grande parte do território nacional (FACHINELLO; NASCIMENTO, 2008).

De acordo com Gonçalves (2011), desde o século XIX até 1930, bem como na atualidade, as ferrovias têm a finalidade precípua de escoamento de produtos

* A revisão gramatical, ortográfica, ABNT ou APA foi realizada pelos autores. 


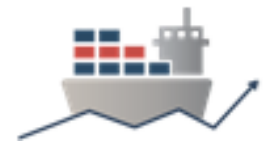

destinados ao comércio exterior, organizados sob a ótica de corredores de exportação, com foco em commodities. Dessa forma, as ferrovias hoje existentes ainda carregam as características oriundas do seu período de construção, como monopólios regionais, com ferrovias isoladas e diferentes bitolas. Características que até hoje dificultam o seu uso para interligação das diferentes regiões do país, e a função de atendimento da demanda interna por produtos.

Sem fluxo inter-regional de transportes, a ferrovia não representa um forte concorrente da cabotagem, ressaltando que, na década de 1930, o modal rodoviário ainda era incipiente e o transporte no interior do país era executado pelos "tropeiros", que atravessavam rios e estradas precárias, para distribuição de mercadorias em curtas distâncias. As poucas estradas eram concentradas na região sudeste, o que reforçou ainda mais a concentração da produção e do consumo na região sudeste do Brasil, processo iniciado desde o período colonial.

Dessa forma, há de se supor que a baixa concorrência com os outros modais contribuiu para a prevalência do uso da navegação como meio de transporte para abastecimento de um país com dimensões continentais como o Brasil, com capacidade de atendimento a quatro das cinco regiões do país. A precariedade das estradas até as décadas de 1950/1960 também contribuíram para a hegemonia da cabotagem no país. A partir desse período, os investimentos em infraestrutura passaram a ser focados no modal rodoviário, influenciados pela força da indústria automobilística, no qual construir estradas passou a caracterizar o principal fator de desenvolvimento de um país (FACHINELLO; NASCIMENTO, 2008).

Por conseguinte, a participação relativa da cabotagem na matriz de transportes foi continuamente reduzida, atravessando sucessivas crises econômicas, com os investimentos em transportes convergindo para a construção e manutenção de estradas. Apesar da criação do Fundo da Marinha Mercante e da Superintendência Nacional da Marinha Mercante - SUNAMAM, criadas respectivamente nos finais das décadas de 1950 e 1960, os resultados não foram satisfatórios. De acordo com Goularti Filho (2010), dado os atrasos na entrega das encomendas, a alta inadimplência dos armadores e construtores, que estavam abarrotados de dívidas com a SUNAMAM, extinta pela medida provisória 27 de 15 de janeiro de 1989, resultou numa significante redução da frota da marinha mercante nacional. Todos esses fatores relacionados à qualidade da frota mercante brasileira e à baixa produtividade dos portos brasileiros geraram incertezas em relação a prazo e custos, inibindo o uso da cabotagem. Outro fator é a burocracia para desembaraço de cargas, que pode vir a ser demorado e também impactar prazo e custo.

Nesse cenário, entraram em vigor a Lei $n^{\circ} 8.630 / 93$, a Lei de Modernização dos Portos e o marco regulatório da cabotagem brasileira, com a promulgação da Lei $n^{\circ}$ 9.432/97, com o objetivo de ampliar o uso do modal aquaviário.

O normativo define navegação de cabotagem, segundo o seu art. $2^{\circ}$, IX, "como a realizada entre portos ou pontos do território brasileiro, utilizando a via marítima ou esta e as vias navegáveis interiores". Tal diploma legal se aplica: aos armadores, às empresas de navegação e às embarcações brasileiras; às embarcações estrangeiras afretadas por armadores brasileiros; aos armadores, às empresas de navegação e às embarcações estrangeiras, quando amparados por acordos firmados pela União. Excetuam-se os navios de guerra e de Estado que não estejam empregados em atividades comerciais; as embarcações de esporte e recreio; as embarcações de turismo; as embarcações de pesca; e as embarcações de pesquisa.

A reestruturação dos serviços de cabotagem a partir do marco regulatório, segundo o IPEA (RESSURGIMENTO..., 2014), acompanhou também o processo de 


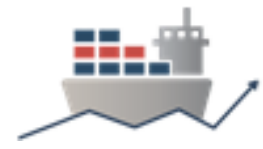

abertura econômica, buscando ultrapassar a fase de substituição de importações que prevaleceu entre as décadas de 1930 e 1990, marcadas por uma forte presença do Estado na economia, passando para uma economia em abertura a partir do início de 1990.

É importante contextualizar as motivações da edição do marco regulatório, além da quase extinção da marinha mercante brasileira, cabendo destacar as principais características do mercado de frete marítimo para melhor compreensão dos impactos dessa medida. O mercado de frete marítimo tem a economia de escala como seu principal vetor de crescimento, operando num ambiente sem regulação e exposto a variações diárias. Dentre os principais fatores de volatilidade estão: a demanda por bens, a oferta de navios, o custo do combustível, os gargalos logísticos, a meteorologia e, mais recentemente, mudanças climáticas.

Por consequência, a lei 9.432/1997 tem como principal objetivo a preservação da frota de cabotagem, mantendo-a em território nacional, evitando-se o deslocamento dessas embarcações para outras regiões do mundo, criando barreiras de entrada e saída para se evitar a descontinuidade na prestação dos serviços de cabotagem, quando o preço do frete estiver mais atrativo em outra parte do mundo.

A lei 9.432/1997 rege o transporte aquaviário e estabelece as regras e condições para a navegação de cabotagem no país, onde somente podem operar as Empresas Brasileiras de Navegação ("EBN"), definidas em lei como: "pessoa jurídica constituída segundo as leis brasileiras, com sede no país, que tenha por objeto o transporte aquaviário, autorizada a operar pelo órgão competente", cuja responsabilidade pela autorização foi delegada à Agência Nacional de Transportes Aquaviários - ANTAQ, após a sua criação em 2001.

Dentre outras atribuições na sua esfera de atuação, a ANTAQ também é responsável pela regulação e fiscalização do funcionamento e da prestação de serviços das empresas no modal aquaviário, estudos para definição de demanda de transporte e definição de tarifas, além dos estudos para estabelecimento de padrões e normas técnicas.

\section{Objetivo e Metodologia de Pesquisa}

O presente artigo apresenta um panorama deste modal no Brasil, a partir da ótica de origem e destino das cargas transportadas pela cabotagem e propõe, a partir da estimativa do transporte rodoviário de carga geral de longa distância, um potencial de substituição deste modal para o mercado de cabotagem de carga geral e contêiner.

O processo de pesquisa foi iniciado pela ANTAQ, com a geração e posterior exportação da sua base de dados para planilha do aplicativo Excel referente ao anuário estatístico de 2018 (ANTAQ, 2018). A base de dados é alimentada pelo Sistema de Desempenho Portuário - SDP, cujo preenchimento é obrigatório para todas as instalações portuárias brasileiras.

A base de dados documenta todo o transporte legalmente caracterizado como cabotagem, realizado no país nos anos de 2017 e 2018. Para cálculo do transporte de cargas é considerada a ação de desembarque, pois neste momento é efetivado o transporte da carga. Na planilha Excel é apresentado para cada mercadoria, a partir do seu código $\mathrm{SH} 2$, seu ponto de origem e destino, registrado por instalação portuária, referente a todo transporte realizado por cabotagem no Brasil durante os dois últimos anos. Entretanto, neste artigo está sendo utilizado somente o ano de 2018.

No tratamento dos dados referente ao transporte de carga conteinerizada, como o código SH2 não apresenta a descrição do contêiner, foi considerado de forma 


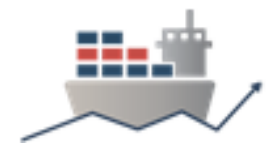

suplementar o código $\mathrm{SH} 4$, no qual é descrito o conteúdo transportado em cada contêiner. O Sistema Harmonizado $(\mathrm{SH})$, na verdade uma sigla condensada de Sistema Harmonizado de Designação e Codificação de Mercadorias, é uma nomenclatura aduaneira, utilizada internacionalmente como um sistema padronizado de codificação e classificação de produtos de importação e exportação, desenvolvido e mantido pela Organização Mundial das Alfândegas. (OMA).

Neste trabalho, foi utilizada como unidade de medida a tonelada líquida para a carga conteinerizada, desconsiderando o peso do contêiner. Para os demais perfis de carga foi utilizada a tonelada, para poder analisar todas as cargas transportadas na mesma unidade de medida, considerando todos os perfis de carga transportados pela cabotagem.

Conservadoramente, devido à alta representatividade da carga geral no modal rodoviário e à dificuldade na obtenção de dados mais detalhados em relação ao fluxo de transporte por produto e por unidade federativa em todos os modais de forma integrada, optou-se por delimitar o potencial de captação pela cabotagem, somente em relação ao modal rodoviário inter-regional de carga geral. Cabe ressaltar que o transporte relacionado à região centro-oeste e o longo curso não foram considerados na matriz de origem e destino analisada neste trabalho, desenvolvida a partir da matriz elaborada no âmbito do PNLI - Plano Nacional de Logística Integrada.

A contextualização foi caracterizada a partir da obtenção de fontes secundárias, cuja revisão bibliográfica objetivou a identificação da contribuição das principais instituições de pesquisa do país como o IPEA (RESSURGIMENTO..., 2014), EPL (EPL, 2015) e Instituto ILOS, (ILOS, 2016), além de pesquisas cientificas devidamente referenciadas no presente trabalho. Ressalta-se que, conforme Gil (2007), os projetos de pesquisa, quase na sua totalidade, inicia-se por esse método, dada a necessidade de construção do referencial teórico, que representa uma característica intrínseca aos projetos acadêmicos, como o presente artigo.

Este artigo é uma pesquisa exploratória sobre a origem e destino das cargas transportadas por cabotagem, assunto com poucos artigos publicados no país.

Entre os principais objetivos do presente artigo estão a procura por padrões, ideias ou hipóteses para propor novas pesquisas que proponham alternativas para o desenvolvimento da cabotagem no Brasil, visando alcançar uma matriz de transportes mais equilibrada entre os diferentes modais que a compõe.

\section{O MERCADO BRASILEIRO DE CABOTAGEM}

A pesquisa sobre os fluxos de origem e destino das mercadorias transportadas pela cabotagem brasileira busca, em primeiro lugar, conhecer e apresentar o que hoje é transportado pelo modal e servir como ponto de partida para pesquisas subsequentes que busquem soluções para o uso da cabotagem no país. A análise da cadeia logística dos principais produtos transportados pela cabotagem, principalmente em relação a carga geral, com demanda inter-regional consistente, com consumo nacional e produção concentrada em regiões próximas ao litoral e que hoje utilizam o modal rodoviário de longa distância, são potencialmente substituíveis pela cabotagem. Outro vetor de crescimento da cabotagem está nas operações logísticas das indústrias de Óleo e Gás, principalmente em relação ao Pré-sal.

\subsection{Matriz de Transportes Mundo}

De acordo com os estudos do Panorama ILOS - Custos Logísticos no Brasil (ILOS, 2016), na matriz de transportes mundial predomina o uso do modal rodoviário. 
Tendo como comparação as regiões mais relevantes do comércio internacional, como os Estados Unidos, União Europeia e China. Pode-se verificar que a China é a exceção, apresentando um maior equilíbrio entre os diferentes modais. E o Brasil apresenta um desequilíbrio na distribuição modal mais acentuado que os demais, concentrando acima de $60 \%$ de participação no transporte rodoviário, conforme apresentado na figura a seguir:

Figura 1 - Matriz de transportes mundial

\section{MATRIZ DE TRANSPORTES (\% DO TKU*)}
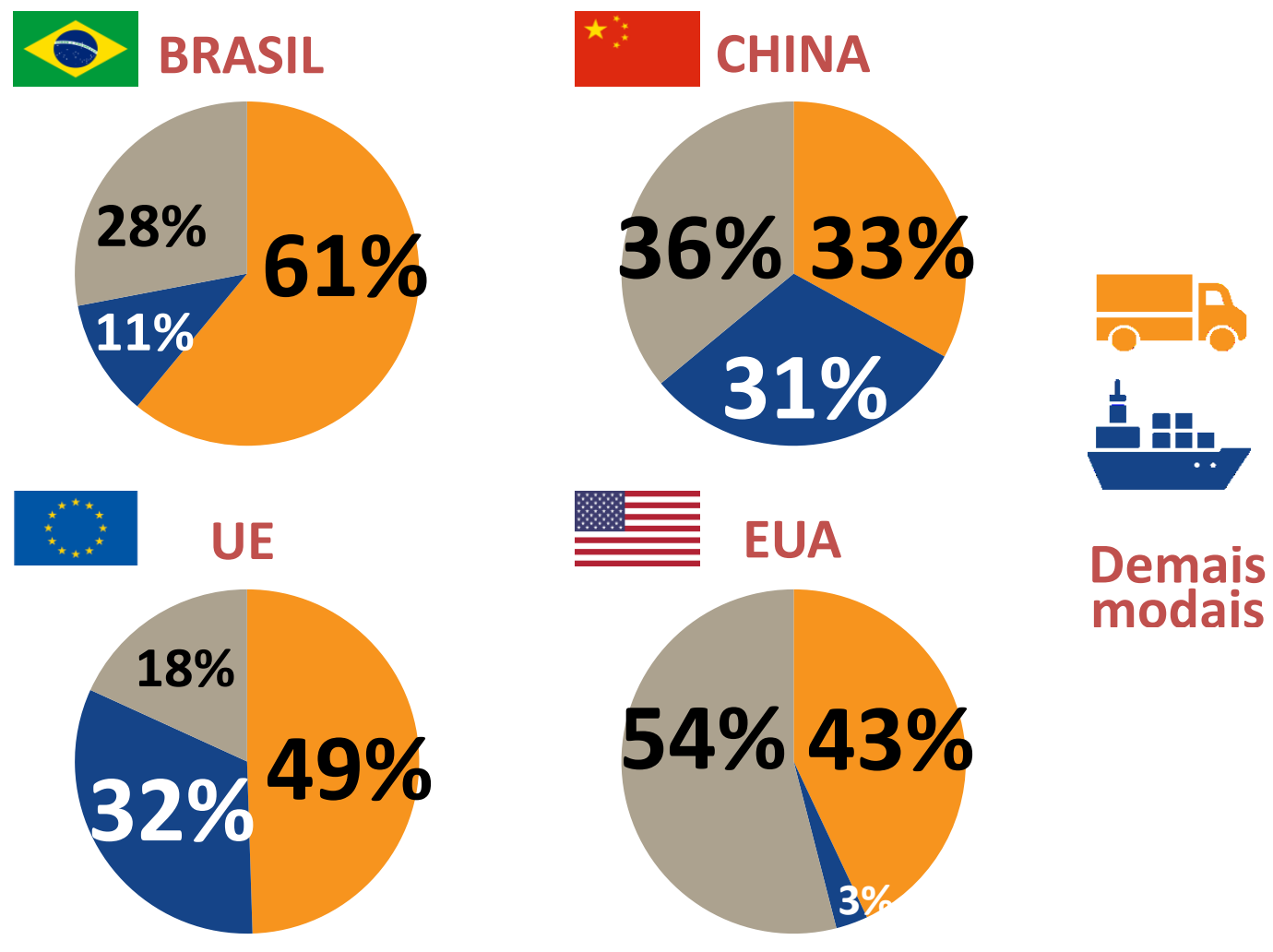

Fonte: ILOS, National Bureau of Statistics of China, Bureau of Transportation Statistics (EUA), Eurostat (EU); *Tonelada Kilômetro Útil

De forma empírica, depreende-se que a participação importante da cabotagem na União Europeia deve-se a características intrínsecas dessa região, como um acordo de livre trânsito entre múltiplos estados-membros, leis e regras infralegais bem definidas, a existência de hidrovias que interligam portos modernos que se interligam às principais rotas transoceânicas, com grande capacidade de movimentação e que geram fluxos de transbordo, hub-feeder, a partir das movimentações de longo curso. As características apresentadas, com um fluxo permanente e relevante de comércio entre os seus países membros fizeram com que a cabotagem tivesse uma participação importante na sua matriz de transportes.

\subsection{Fatores de Restrição da Cabotagem Brasileira}

A matriz de transportes brasileira, com concentração acima de $60 \%$ do transporte rodoviário, é desequilibrada por diversos fatores, dentre os quais pode-se destacar o foco dos investimentos em transporte rodoviário desde as décadas de 1950 


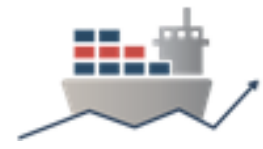

e 1960 até os dias atuais, exemplificados pelos subsídios para o preço do diesel, incentivos às indústrias automobilísticas com desoneração tributária na aquisição de veículos, priorização de investimentos para construção de estradas e, mais recentemente, o tabelamento dos preços do frete rodoviário.

Segundo Silveira Junior (2018), além das questões externas ao modal, existem fatores intrínsecos, como: infraestrutura portuária; procedimentos portuários; custos portuários; marco regulatório, e; politicas públicas que restringem o desenvolvimento da cabotagem para os perfis de carga para o qual é vocacionado, como o transporte em longas distâncias e grandes volumes. Esses fatores restringem o desenvolvimento das Empresas Brasileiras de Navegação - EBN e dificulta um aumento da participação relativa da cabotagem na matriz de transportes brasileira.

Os dois principais fatores de restrição, apontados por Silveira Junior (2018), foram relacionados aos custos portuários e ao marco regulatório, tido aqui num sentido mais amplo, incluindo normas e procedimentos. As principais questões levantadas são relacionadas principalmente à carga tributária, restrição dos casos de dispensa de prático e o respectivo custo de praticagem. Aspectos como o custo do bunker, desequilíbrio nos fluxos entre os eixos Sul-Norte e Norte-Sul, além da falta de disponibilidade da indústria naval brasileira e os seus respectivos custos e riscos de conclusão também foram apontados como relevantes. Tais fatores podem ter um encaminhamento positivo, caso sejam contemplados no planejamento da matriz de transportes do país, com medidas que visem à redução do seu desequilíbrio.

\subsection{Matriz de Transportes Brasileira}

O principal fator para o desenvolvimento de qualquer indústria, dentre elas as indústrias prestadoras de serviços de transportes de carga, é a existência de oferta e demanda por bens, premissa básica para que haja demanda por serviços de transportes. A partir desta premissa, os produtores buscam otimizar sua estrutura de custos para maximizar seu resultado econômico-financeiro e a satisfação do seu cliente, entregando o produto no prazo, preço e qualidade contratada. Neste momento o produtor considera os diferentes modais para a entrega do seu produto ao consumidor final, no qual o preço, a distância a ser percorrida, o prazo de entrega e o volume a ser transportado são essenciais para a escolha do modal que vai possibilitar a maximização do seu resultado e atendimento da demanda com a qualidade desejada. Conforme apresentado na Tabela 4, o modal aquaviário é o mais econômico em relação a custo, redução de emissões de $\mathrm{CO}_{2}$ e registra menos acidentes para o transporte em longas distâncias e grandes volumes.

A acentuada participação do modal rodoviário também é derivada da alta concentração comercial na região sudeste, por concentrar grande parte da população, caracterizando-se como o principal centro consumidor e produtor de bens e serviços, dificultando a opção pelo modal aquaviário para o transporte em curtas distâncias a serem percorridas na própria região. Além da curta distância, o baixo volume e a alta capilaridade das entregas de carga geral e produtos agrícolas para o mercado doméstico, dentro da mesma região, são opções naturais para o uso do modal rodoviário, ou ferroviário em alguns casos, contribuindo para o desequilíbrio da matriz de transportes brasileira, conforme apresentado a seguir: 
VI CIDESPORT/2019

Congresso Internacional

de Desempenho Portuário

Figura 2 - Distribuição modal da matriz de transportes brasileira

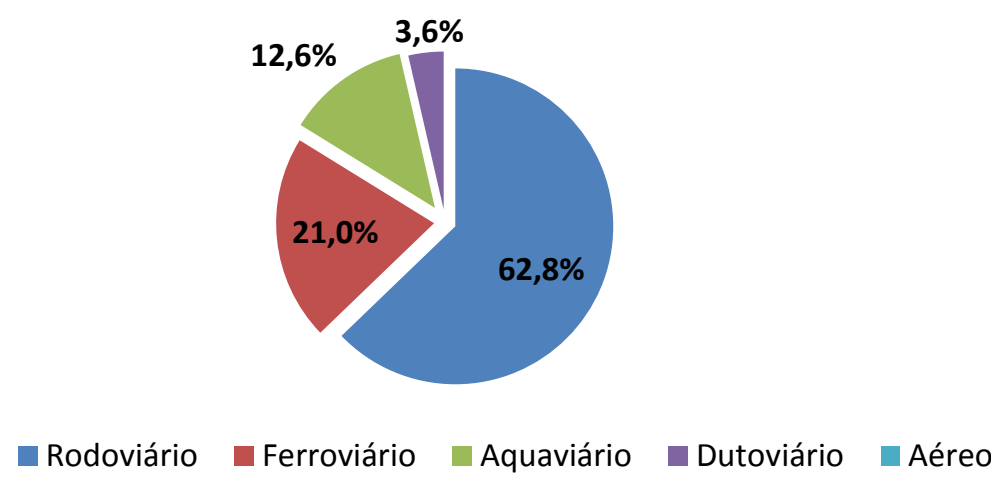

Fonte: Panorama ILOS - Custos Logísticos no Brasil (2016)

Cabe ressaltar que a alta concentração do transporte por cabotagem na região sudeste, respondendo por $53 \%$ de todo transporte realizado pelo modal durante o ano de 2018, se refere ao escoamento da produção de petróleo e gás realizados no litoral do Sudeste, nas águas territoriais brasileiras, caracterizada pela distância de até 200 milhas náuticas da costa. Os estados de Rio de Janeiro, São Paulo e Espírito Santo são responsáveis por mais de $80 \%$ de toda a produção nacional. Como quase toda a prospecção ocorre no mar, o transporte do produto até as refinarias é exclusivo da cabotagem, devido à impossibilidade de concorrência com outros modais e a ausência de oleodutos.

Tabela 1 - Matriz de origem e destino - Volume transportado - 2018

\begin{tabular}{|c|rrrrrr|}
\multicolumn{7}{|c|}{$\begin{array}{c}\text { Matriz Origem - Destino de Volume Transportado } \\
\text { Cabotagem 2018 - Em mil ton) }\end{array}$} \\
\hline \multirow{2}{*}{ Origem } & \multicolumn{7}{c|}{ Destino } \\
\cline { 2 - 8 } & Norte & Nordeste & Sudeste & Sul & Centro-Oeste & \multicolumn{1}{c|}{ Total } \\
\hline Norte & $2.657,3$ & $10.863,7$ & $1.187,0$ & 311,8 & - & $15.019,8$ \\
Nordeste & $4.412,0$ & $14.170,0$ & $10.656,2$ & $1.912,3$ & - & $31.150,5$ \\
Sudeste & $1.644,4$ & $18.174,3$ & $73.352,7$ & $18.118,0$ & - & $111.289,4$ \\
Sul & 725,6 & $2.698,9$ & $1.374,2$ & 550,0 & - & $5.348,7$ \\
Centro-Oeste & - & - & 181,2 & - & - & 181,2 \\
\hline Total & $\mathbf{9 . 4 3 9 , 3}$ & $\mathbf{4 5 . 9 0 6 , 9}$ & $\mathbf{8 6 . 7 5 1 , 3}$ & $\mathbf{2 0 . 8 9 2 , 1}$ & - & $\mathbf{1 6 2 . 9 8 9 , 6}$ \\
\hline
\end{tabular}

\begin{tabular}{|c|cccccc|}
\hline \multirow{2}{*}{ Origem } & \multicolumn{6}{|c|}{ Destino } \\
\cline { 2 - 6 } & Norte & Nordeste & Sudeste & Sul & Centro-Oeste & Total \\
\hline Norte & $2 \%$ & $7 \%$ & $1 \%$ & $0 \%$ & $0 \%$ & $10 \%$ \\
Nordeste & $3 \%$ & $9 \%$ & $7 \%$ & $1 \%$ & $0 \%$ & $20 \%$ \\
Sudeste & $1 \%$ & $11 \%$ & $45 \%$ & $11 \%$ & $0 \%$ & $67 \%$ \\
Sul & $0 \%$ & $2 \%$ & $1 \%$ & $0 \%$ & $0 \%$ & $3 \%$ \\
Centro-Oeste & $0 \%$ & $0 \%$ & $0 \%$ & $0 \%$ & $0 \%$ & $0 \%$ \\
\hline Total & $\mathbf{6 \%}$ & $\mathbf{2 8 \%}$ & $\mathbf{5 3 \%}$ & $\mathbf{1 2 \%}$ & $\mathbf{0 \%}$ & $\mathbf{1 0 0 \%}$ \\
\hline
\end{tabular}

Além da acentuada concentração geográfica da cabotagem na região sudeste, o modal transporta quase na sua totalidade produtos em granel. $\mathrm{O}$ grupo granéis 
responde por $91 \%$ do total transportado em 2018. Ressaltando que apenas o grupo granéis líquidos, principal perfil de carga transportado pela cabotagem, respondeu por $73 \%$ desse total, conforme ilustra a figura a seguir:

Figura 3 - Cabotagem - 2018 - Participação percentual por perfil de carga

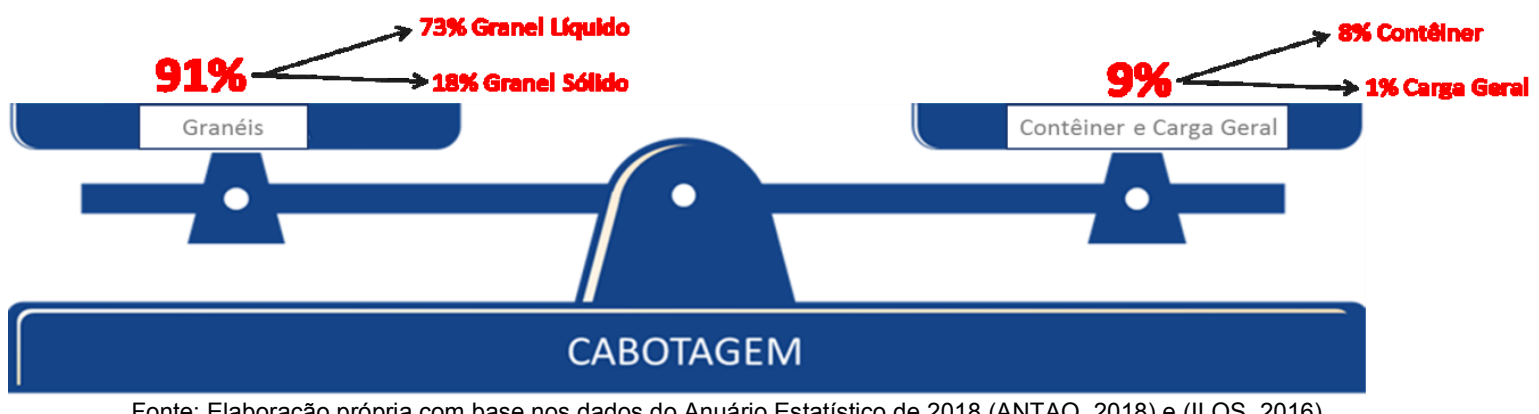

Fonte: Elaboração própria com base nos dados do Anuário Estatístico de 2018 (ANTAQ, 2018) e (ILOS, 2016)

A partir do notório desbalanceamento da matriz de transportes do país, aprofundado pela concentração elevada em relação ao transporte de granéis líquidos, que não configuram economicamente o mesmo mercado que os demais perfis de carga, apenas representam a logística empresarial do setor de Óleo e Gás, principalmente da Petrobrás. Propomos pela análise dos fluxos de origem e destino da cabotagem, com o detalhamento dos principais produtos transportados pelo modal, apresentar o cenário com e sem os granéis líquidos, com o objetivo de entender e procurar fomentar o uso da navegação para as cadeias logísticas de produtos que sejam elegíveis ao seu uso, principalmente em relação ao grupo carga geral e contêiner.

A substituição do modal rodoviário pela cabotagem visa à potencial redução dos custos logísticos, redução do número de acidentes, emissões de $\mathrm{CO}_{2}$ e os custos de manutenção das rodovias e contribuir para um menor desequilíbrio da nossa matriz.

\section{CABOTAGEM BRASILEIRA - ANÁLISE ORIGEM E DESTINO}

Segundo ANTAQ (2018), com base na análise dos volumes transportados pela cabotagem, pode-se afirmar que hoje a cabotagem brasileira é dedicada ao transporte de granéis líquidos, responsáveis por $73 \%$ do total transportado no ano de 2018 . Entretanto, cabe destacar novamente, que o transporte de petróleo cru das plataformas localizadas no mar, para as refinarias em terra, apesar de juridicamente caracterizarem-se como operações de cabotagem, no sentido econômico essas operações de granéis líquidos não são cabotagem, elas são operações logísticas das empresas de Óleo e Gás que devido a inviabilidade da opção pelos oleodutos, só podem executar esse transporte pelo modal aquaviário, não concorrendo com outros modais. Em relação aos dois outros mercados de cabotagem: carga geral e contêiner; e, demais commodities existem um ambiente de competição intermodal. Para uma melhor comparação do tamanho da cabotagem em relação ao volume transportado pelo modal aquaviário é apresentada a Figura 4. E para a apresentação da participação relativa de cada perfil de carga transportada especificamente pela cabotagem é apresentada a Figura 5: 
VI CIDESPORT/2019

Congresso Internacional

de Desempenho Portuário

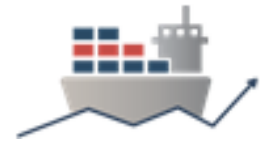

Figura 4 - Volume transportado no modal aquaviário em 2018 (1,025 bilhão toneladas)

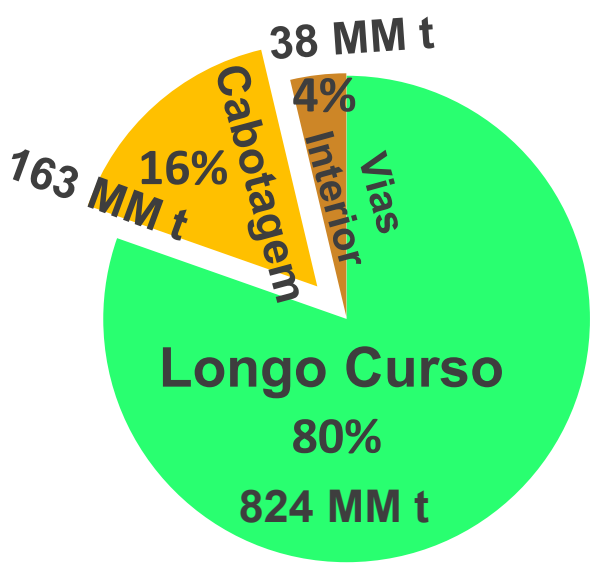

Fonte: Elaboração própria com base nos dados do anuário estatístico de 2018 (ANTAQ, 2018)

Figura 5 - Volume transportado no modal aquaviário em 2018 por perfil de carga

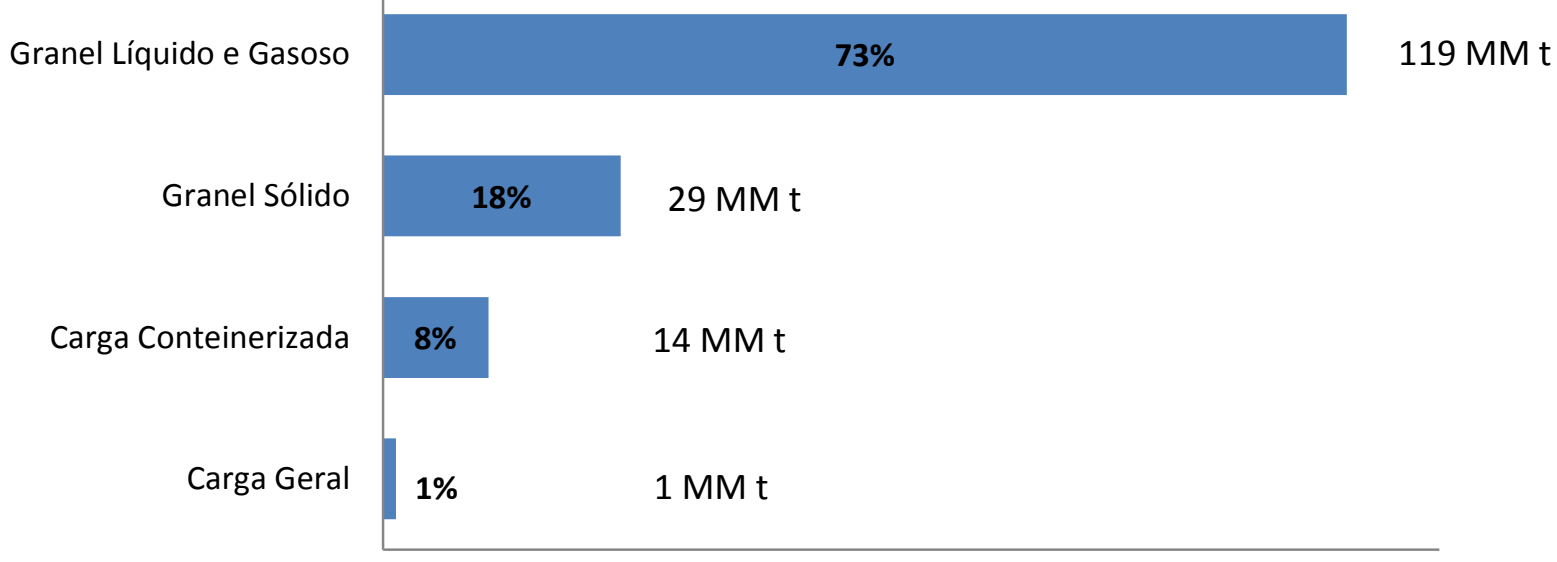

Fonte: Elaboração própria com base nos dados do anuário estatístico de 2018 (ANTAQ, 2018)

\subsection{Cabotagem Brasileira - Principais produtos}

Tendo por base a participação de cada perfil de carga transportada e a sua respectiva participação, apresentado neste retrato do anuário da ANTAQ (2018), será analisado em pormenores para melhor entendimento da dinâmica do transporte aquaviário, os principais produtos transportados pelo modal.

A ANTAQ através dos seus estudos de oferta e demanda, dentro do seu escopo de atuação, elencou as principais rotas da cabotagem brasileira que serve de preâmbulo para o detalhamento que virá a seguir:

i. Transporte de Combustíveis e Óleos Minerais: Grande destaque da cabotagem brasileira dá suporte à cadeia de transporte do petróleo extraído em águas profundas; 
ii.Transporte de Bauxita: TUP Porto Trombetas-PA/Vila do Conde-PA - TUP OMNIA-PA/TUP ALUMAR-MA - TUP Porto Trombetas-PA/TUP ALUMAR-MA. Viabiliza a cadeia produtiva do alumínio nos estados do Maranhão e Pará;

iii.Transporte de Produtos Florestais (Madeira e Celulose): TUP FIBRIA-BA /TUP PORTOCEL-ES - TUP Marítimo de Belmonte-BA/TUP PORTOCEL-ES. Abastece a indústria do papel retirando milhares de caminhões das rodovias brasileiras por ano;

iv.Transporte de Bobina: Porto de Vitória/Porto de São Francisco do Sul - TUP Praia Mole-ES/Porto de São Francisco do Sul. Abastece a indústria metalúrgica do sul do país;

v.Transporte de Produtos da Zona Franca de Manaus: TUP Chibatão-AM/Santos - TUP Superterminais-AM/Santos. Transporte em contêineres de produtos de maior valor agregado, fabricados na Zona Franca de Manaus; e,

vi.Transporte de Sal: Areia Branca-RN/Porto de Santos. Utilizado para consumo e como insumo para a indústria de base como: cloro, alimentos pré-prontos, dentre outros.

\subsection{Mercado - Combustíveis (Granéis Líquidos)}

\subsubsection{Combustível - Análise Origem e Destino}

O principal destaque da cabotagem brasileira, com uma representatividade muito acima dos demais, conforme destacado pelo anuário estatístico de 2018 (ANTAQ, 2018) é o transporte de petróleo numa Industrial Operation da Petrobrás. A operação é caracterizada pela sua verticalização, no qual grandes produtores que são proprietários tanto do navio quanto da carga operam por conta própria toda a cadeia produtiva. Portanto, a cabotagem de granéis líquidos caracteriza-se como uma operação logística das empresas de Óleo e Gás, ao invés de seguir a lógica econômica num ambiente de competição com outros modais.

Até o início da década de 1980 preponderava a produção de petróleo em terra. Entretanto, após a quebra do monopólio da prospecção de petróleo no final da década de 1990, tanto a Petrobrás quanto operadoras estrangeiras focaram os seus investimentos em upstream, prospecção de petróleo cru, nas águas territoriais brasileiras. Atualmente, mais de $80 \%$ da produção nacional é prospectada em águas profundas, com destaque para a exploração na camada do pré-sal, camada de sal soterrada no fundo do mar, com reservas estimadas em aproximadamente 23 milhões de barris (MMbbl), segundo o Boletim de Recursos e Reservas de Petróleo e Gás Natural 2018 publicado pela ANP através da sua Superintendência de Desenvolvimento e Produção - SDP.

Tabela 2 - Volumes Declarados pelos Operadores, discriminados por ambiente e bacia - 2018.

\begin{tabular}{|c|c|c|c|c|c|c|}
\hline \multicolumn{4}{|c|}{ Petróleo $\left(\mathrm{MMm}^{3}\right)$} & \multicolumn{3}{|c|}{ Gás natural $\left(\mathrm{MMm}^{3}\right)$} \\
\hline Mar & & & $\operatorname{Res}$ & & & \\
\hline Alagoas & 0,04 & 0,04 & 0,00 & 341,39 & 341,39 & 0,00 \\
\hline
\end{tabular}


VI CIDESPORT/2019

Congresso Internacional de Desempenho Portuário

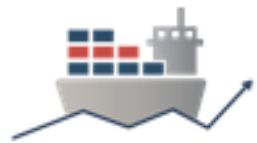

\begin{tabular}{|c|c|c|c|c|c|c|}
\hline Camamu & 3,73 & 14,27 & 0,05 & $5.800,69$ & $8.328,30$ & $2.264,78$ \\
\hline Campos & 779,65 & $1.158,28$ & 543,88 & $78.996,77$ & $118.617,06$ & $46.716,03$ \\
\hline Ceará & 4,39 & 4,49 & 2,38 & 353,81 & 359,90 & 60,52 \\
\hline Espírito Santo & 5,68 & 8,51 & 0,13 & $4.516,12$ & $8.812,89$ & $1.385,42$ \\
\hline Potiguar & 11,12 & 17,28 & 0,12 & $1.849,74$ & $2.827,34$ & 142,20 \\
\hline Recôncavo & 0,10 & 0,19 & 0,02 & 0,00 & 0,00 & 0,00 \\
\hline Santos & $1.217,72$ & $2.468,96$ & 175,66 & $207.512,50$ & $348.315,22$ & $18.643,94$ \\
\hline Sergipe & 0,50 & 1,12 & 6,69 & 81,65 & 157,60 & $2.951,10$ \\
\hline Mar Total & $2.022,93$ & $3.673,14$ & 728,92 & $299.452,66$ & $487.759,71$ & $72.164,00$ \\
\hline \multicolumn{7}{|l|}{ Terra } \\
\hline Alagoas & 0,51 & 0,85 & 0,51 & 867,51 & $2.238,56$ & 606,46 \\
\hline Amazonas & 0,00 & 0,00 & 0,00 & $3.631,00$ & $4.303,30$ & 0,00 \\
\hline Barreirinhas & 0,00 & 0,00 & 0,00 & 143,78 & 143,78 & 0,00 \\
\hline Camamu & 0,00 & 4,36 & 0,01 & 34,88 & 34,88 & 0,00 \\
\hline Espírito Santo & 4,43 & 7,59 & 3,45 & 213,99 & 395,73 & 182,34 \\
\hline Mucuri & 0,00 & 0,00 & 0,00 & 0,00 & 0,00 & 0,00 \\
\hline Parnaíba & 0,04 & 0,04 & 0,00 & $20.528,68$ & $25.576,98$ & 0,00 \\
\hline Potiguar & 21,00 & 26,47 & 11,78 & $1.572,56$ & $1.948,48$ & 108,48 \\
\hline Recôncavo & 20,11 & 30,54 & 8,95 & $5.630,79$ & $9.344,25$ & $1.971,19$ \\
\hline Sergipe & 28,83 & 41,67 & 18,13 & $1.093,97$ & $1.308,59$ & 283,72 \\
\hline Solimões & 6,91 & 7,27 & 0,84 & $35.260,19$ & $36.770,55$ & $5.735,36$ \\
\hline Tucano Sul & 0,00 & 0,00 & 0,00 & 20,46 & 20,46 & 49,66 \\
\hline Terra Total & 81,83 & 118,80 & 43,66 & $68.997,82$ & $82.085,57$ & $8.937,20$ \\
\hline Total $\left(\mathrm{MMm}^{\mathbf{3}}\right)$ & $2.104,76$ & $3.791,93$ & 772,59 & $368.450,48$ & $569.845,28$ & $81.101,20$ \\
\hline Total (MMbbl) & $13.238,53$ & $23.850,54$ & $4.859,42$ & - & - & - \\
\hline
\end{tabular}

Fonte: ANP (2018, p. 4)

As Figuras 6 e 7 apresentam a origem e o destino dos principais produtos transportados pela cabotagem durante o ano de 2018, ranqueados por tonelada transportada, incluindo granéis líquidos, representando graficamente o fluxo de transportes das principais rotas estabelecidas e por consequência seus principais produtos.

Figura 6 - Origem das mercadorias transportadas pela cabotagem em 2018, por unidade federativa, com destaque para combustíveis. 


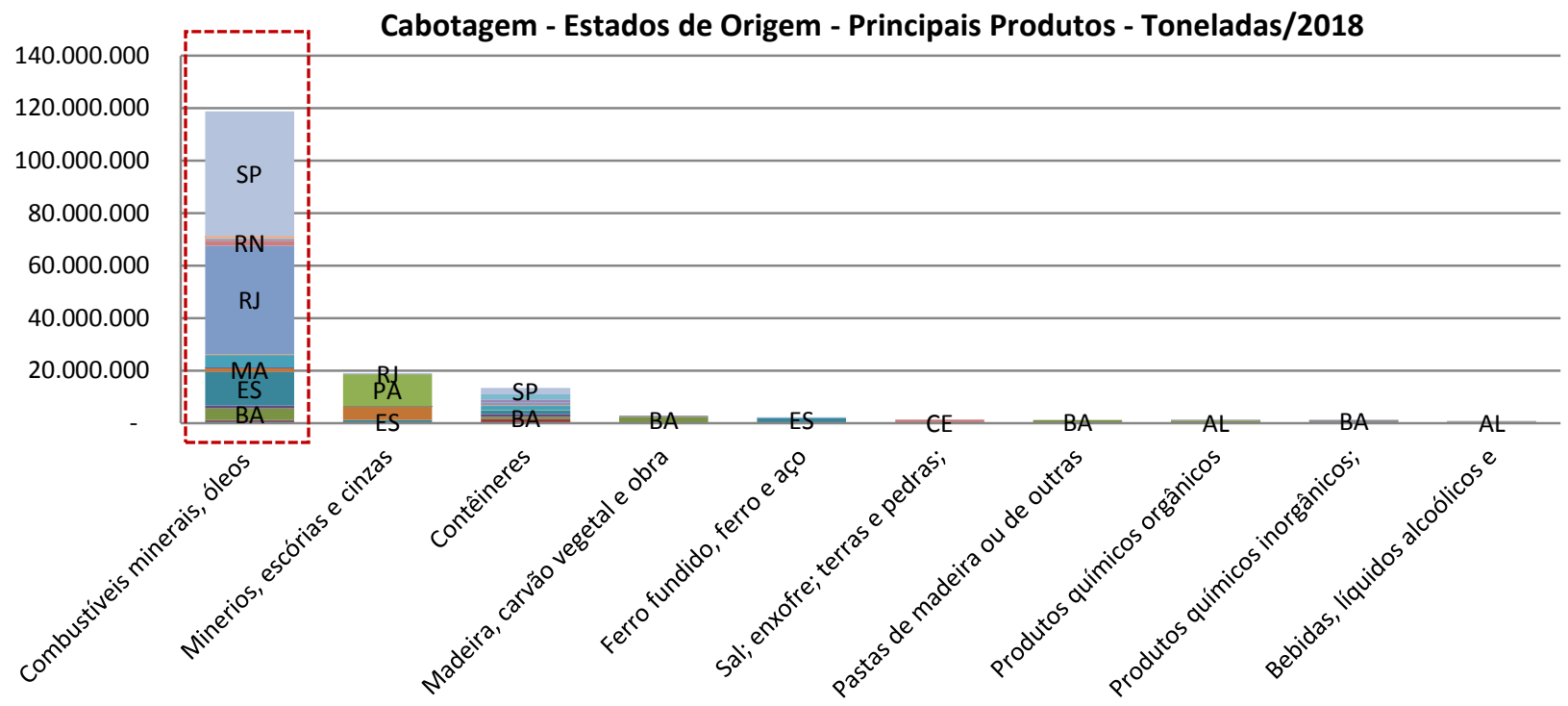

Fonte: Elaboração própria com base nos dados do anuário estatístico de 2018 (ANTAQ, 2018)

Figura 7 - Destino das mercadorias transportadas pela cabotagem em 2018, por unidade federativa, com destaque para combustíveis.

\section{Cabotagem - Estados de Destino - Principais Produtos - Toneladas/2018}

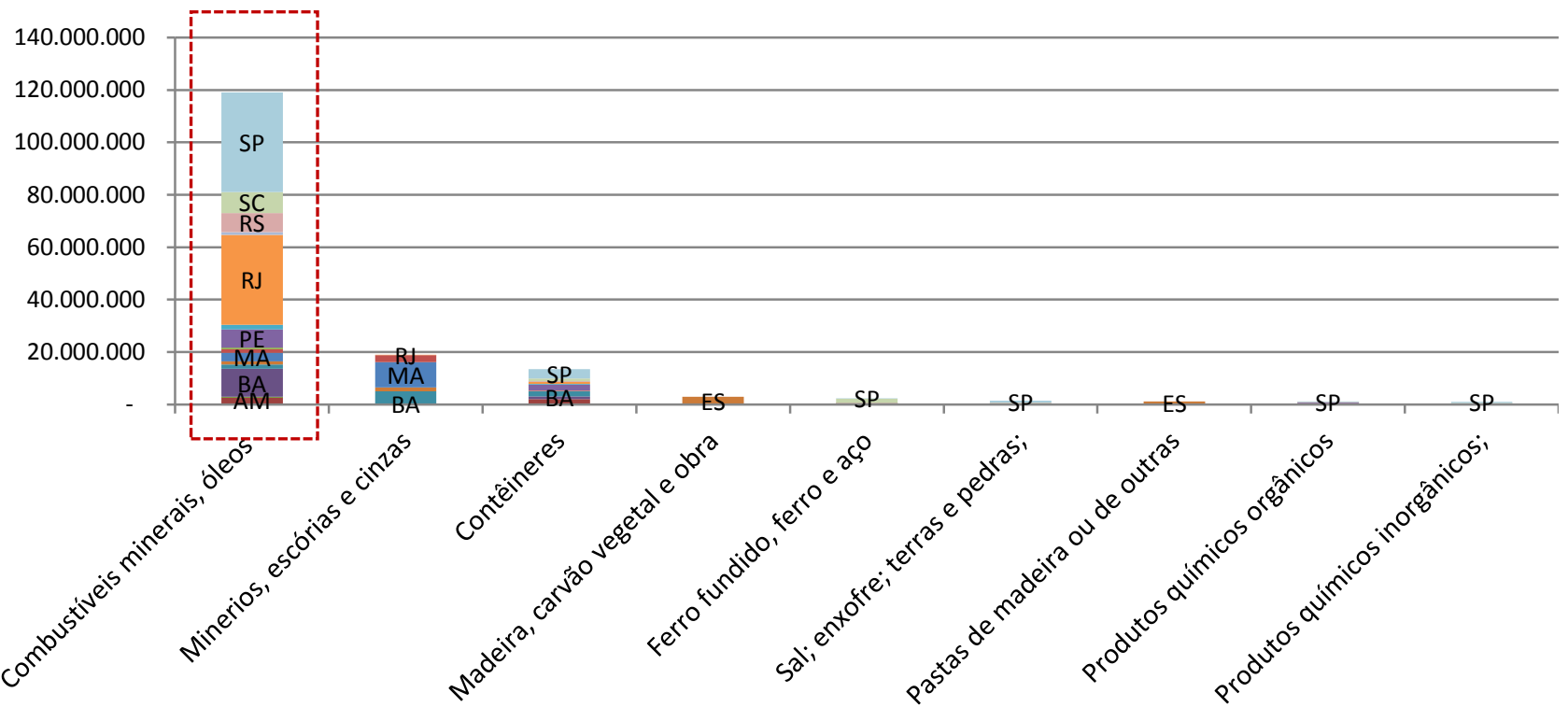

Fonte: Elaboração própria com base nos dados do anuário estatístico de 2018 (ANTAQ, 2018)

O transporte de granéis líquidos por cabotagem apresenta uma tendência de crescimento para os próximos anos, baseado na decisão econômica das empresas de Óleo e Gás que, em última análise, caso no futuro seja viável economicamente, poderiam optar pela construção de um oleoduto. Portanto, o mercado de cabotagem de granéis líquidos não se caracteriza pela competição com outros modais para o 
transporte de combustível das plataformas localizadas no mar para as refinarias, sendo uma decisão logística das empresas de Óleo e Gás. O downstream caracterizado pelo refino e distribuição para o interior do país, se transportado pelo modal aquaviário, apresenta uma dinâmica de competição entre os diferentes modais, como: rodoviário, ferroviário, dutoviário.

\subsection{Minérios - Bauxita e outros}

Os granéis sólidos representam o segundo perfil de carga mais transportado pela cabotagem brasileira, com destaque para a rota da bauxita, matéria-prima na produção do alumínio e representa o segundo mercado dentro da lógica econômica da cabotagem brasileira. Dos três mercados abordados neste estudo, o de cabotagem de granéis sólidos é o que menos tem perspectiva de crescimento, sendo a opção de escoamento de algumas indústrias, como por exemplo, a bauxita da Alunorte transportada nos navios da Elcano e da madeira transportada pela Suzano nos navios da Norsul. A ANTAQ caracteriza esta rota como uma das seis rotas de cabotagem já consolidadas no país. Outro fator que inibe o crescimento deste mercado é o fato de que não há potencial para transporte desse modal no principal centro de produção de granéis sólidos agrícolas do país, que é a região centro-oeste.

O Quadro 1 apresenta o fluxo de origem e destino referente ao transporte da bauxita. As rotas existentes interligam os principais centros produtores, onde se encontram as maiores jazidas de bauxita, localizadas no estado do Pará, com as siderúrgicas situadas nos estados de Pará e Maranhão, além dos estados de Minas Gerais e Goiás.

Segundo o Ministério dos Transportes, Portos e Aviação Civil - MTPAC (BRASIL, 2018), o consumo interno da commodity é avaliado em $75,3 \%$, considerando a produção total do país em 2017 de 27,4 milhões de toneladas. Segue de forma segmentada a cadeia logística de transportes da Bauxita no Brasil em 2017.

Quadro 1 - Origem e destino da bauxita transportada no mercado interno em 2018, por modal

\begin{tabular}{|c|c|}
\hline \multicolumn{2}{|c|}{ Cabotagem: 13,5 milhões t. } \\
\hline Origem & Destino \\
\hline $\begin{array}{l}\text { Porto do Açu - Terminal de Minério } \\
\text { Rio de Janeiro (RJ) } \\
\text { Terminal Fluvial de Juruti (PA) } \\
\text { Terminal Trombetas (PA) } \\
\text { Terminal Trombetas (PA) } \\
\end{array}$ & $\begin{array}{l}\text { Terminal Portuário Privativo da Alumar (MA) } \\
\text { Vila do Conde (PA) } \\
\text { Terminal Portuário Privativo da Alumar (MA) } \\
\text { Terminal Portuário Privativo da Alumar (MA) } \\
\text { Vila do Conde (PA) }\end{array}$ \\
\hline \multicolumn{2}{|c|}{ Mineroduto: 11,4 milhões t } \\
\hline Paragominas (PA) & Barcarena (PA) \\
\hline \multicolumn{2}{|l|}{ Ferroviário: 2 milhões t. } \\
\hline \multicolumn{2}{|l|}{ FCA } \\
\hline $\begin{array}{l}\text { Brasília (DF) } \\
\text { Bauxita (MG) }\end{array}$ & $\begin{array}{l}\text { Alumínio (SP) } \\
\text { Alumínio (SP) }\end{array}$ \\
\hline \multicolumn{2}{|l|}{ MRS } \\
\hline Barão de Angra (RJ) & Alumínio (SP) \\
\hline
\end{tabular}

Fonte: Elaboração própria com base nos dados do Anuário Estatístico de Transportes 2010-2017 do MTPAC 
Os valores referentes ao transporte de combustíveis, devido a sua lógica econômica distinta das demais, representada pelas operações logísticas da indústria de Óleo e Gás, foram retirados do gráfico para uma melhor visualização relativa dos demais produtos, dada à desproporcionalidade da participação dos granéis líquidos no total transportado.

\subsubsection{Mercado - Commodities (Granéis Sólidos não Agrícolas)}

Figura 8 - Origem das mercadorias transportadas pela cabotagem em 2018, por unidade federativa, com destaque para minérios (bauxita)

\section{Cabotagem - Estados de Origem - Principais Produtos - Toneladas/2018}

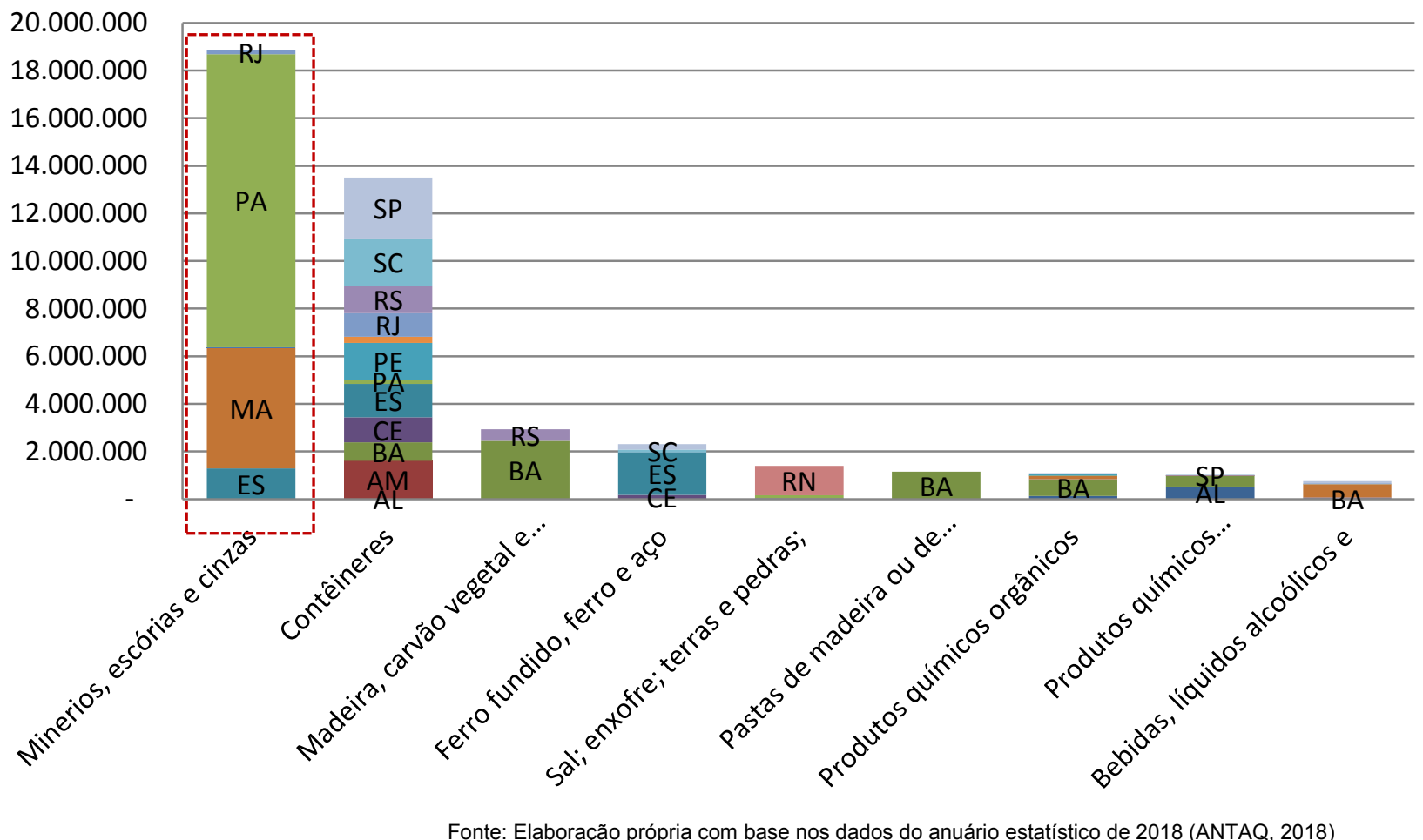


VI CIDESPORT/2019

Congresso Internacional

de Desempenho Portuário

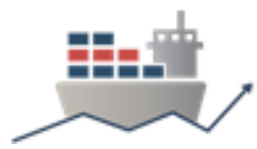

Figura 9 - Destino das mercadorias transportadas pela cabotagem em 2018, por unidade federativa, com destaque para minérios (bauxita)

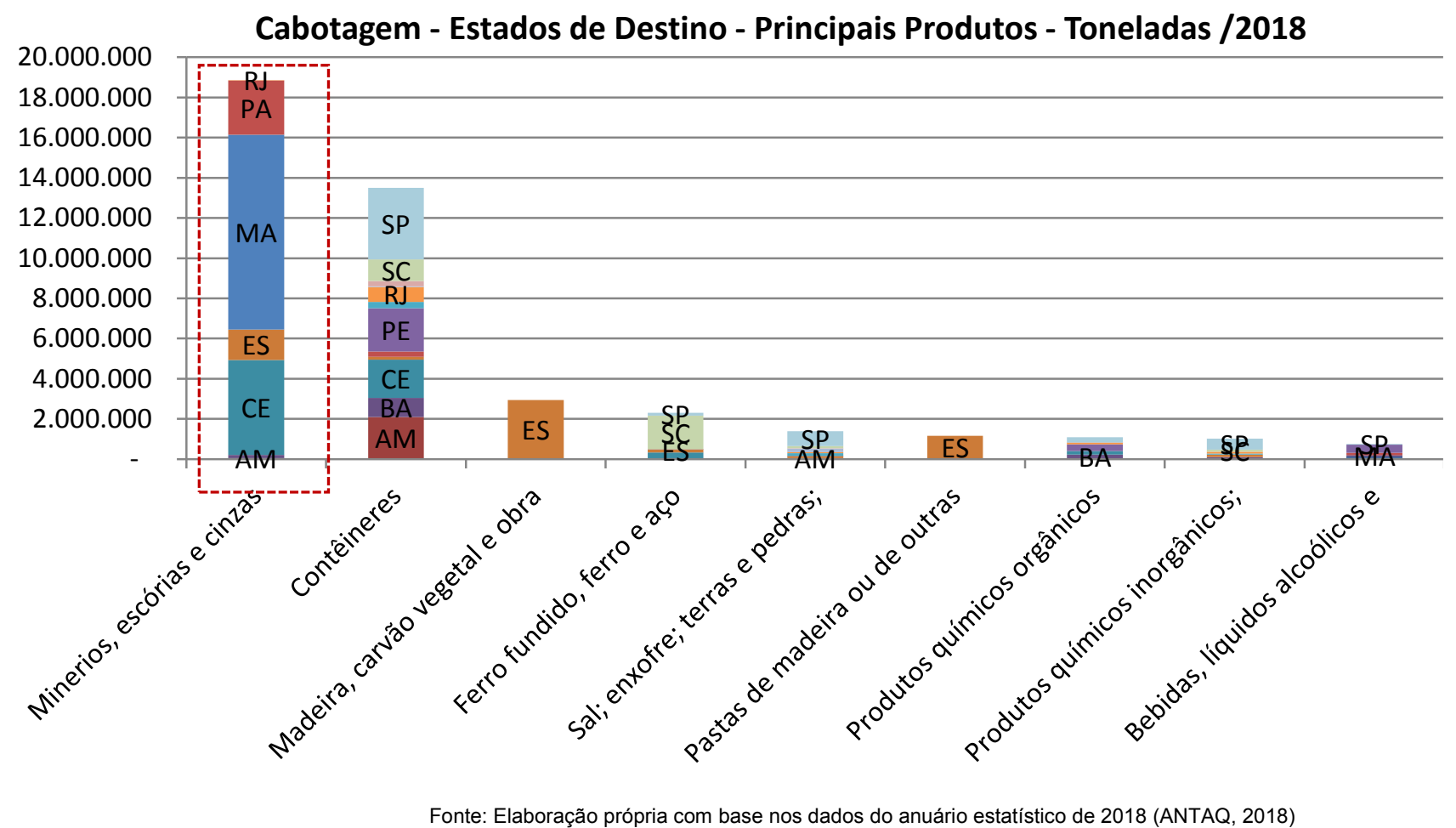

\subsection{CONTÊINERES}

Os contêineres representam o terceiro perfil de carga mais transportado pela cabotagem brasileira e, bem como os demais, representa uma lógica econômica que os distinguem dos anteriores, caracterizando-se como o terceiro mercado representado neste estudo. Os produtos transportados por contêineres apresentam uma grande diversidade, inclusive em relação à quantidade de empresas que demandam os serviços de transporte marítimo, pois do lado da oferta o mercado apresenta um alto grau de concentração. A diversidade de clientes atuais e potenciais no setor de contêineres é um fator que os distinguem das cadeias logísticas do petróleo e da bauxita (minérios).

Estas duas são dedicadas especificamente ao escoamento destes produtos em operações verticalizadas sem uma multiplicidade de atores econômicos.

As Figuras 10 e 11 apresentam o fluxo de origem e destino, sem granéis líquidos, referente a linhas regulares de contêineres.

\subsubsection{Mercado - Contêineres}


VI CIDESPORT/2019

Congresso Internacional

de Desempenho Portuário

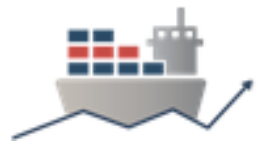

Figura 10 - Origem das mercadorias transportadas pela cabotagem em 2018, por unidade federativa, com destaque para contêineres

\section{Cabotagem - Estados de Origem - Principais Produtos - Toneladas/2018}

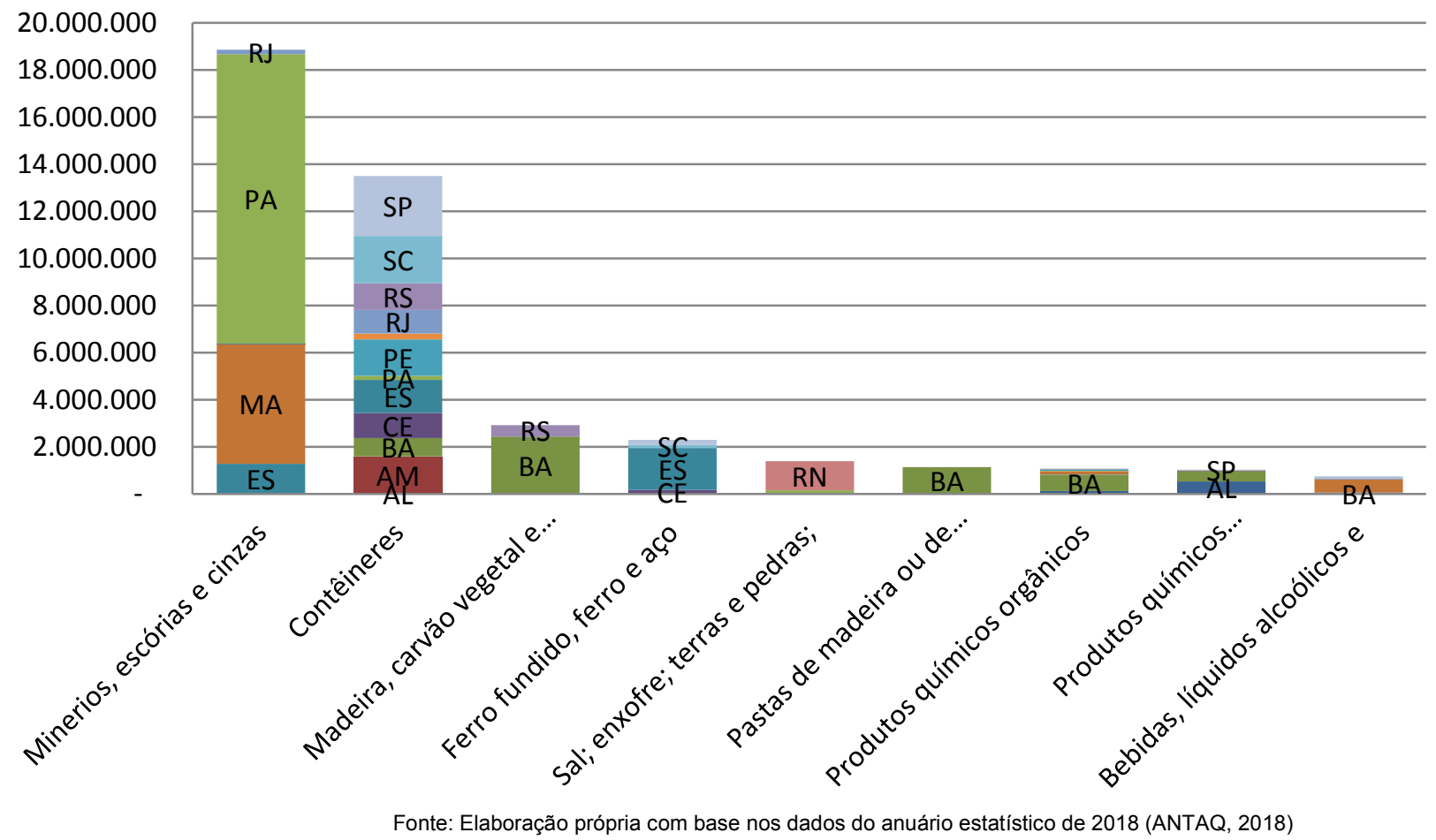

Figura 11 - Destino das mercadorias transportadas pela cabotagem em 2018, por unidade federativa, com destaque para contêineres

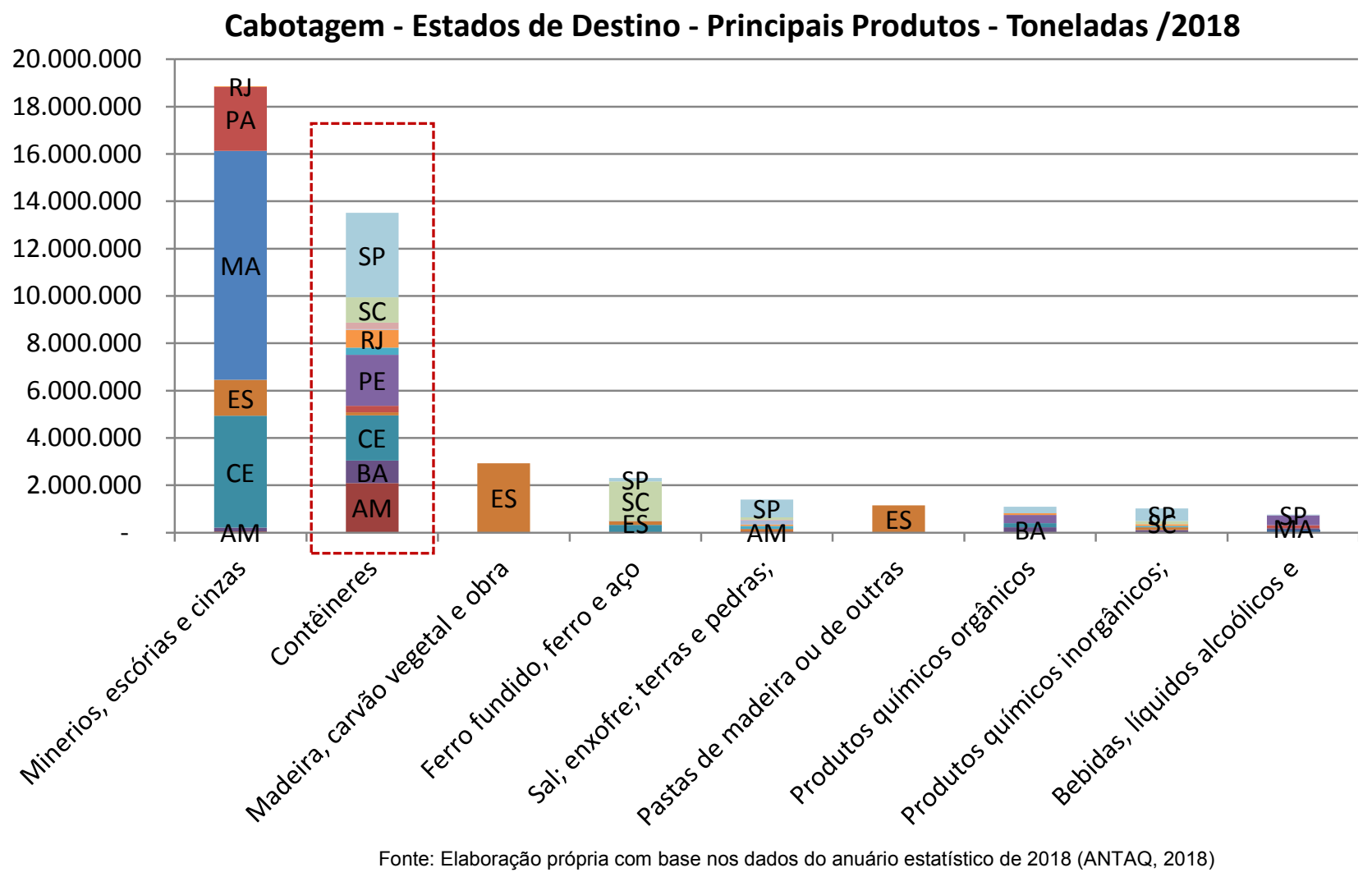




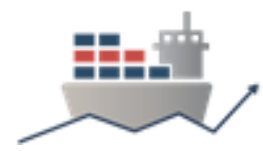

As Figuras 10 e 11 representam as rotas hoje existentes aqui consolidadas por unidade da federação e operadas pelas três empresas do setor de contêineres: Aliança Navegação, Mercosul Line e Log-In.

Ressalta-se que o maior potencial de crescimento deste mercado está atualmente na propensão e incentivo à substituição do modal rodoviário de longas distâncias e grandes volumes pelos contêineres transportados ao longo da costa brasileira, principalmente em relação ao grupo de mercadorias carga geral. Esse potencial de crescimento tende a desenvolver novas cadeias logísticas, para o transporte de produtos que atualmente se utilizam do modal rodoviário. Esse incentivo não representa necessariamente a concessão de subsídios, mas como já foi apresentado durante a Contextualização, com alterações regulatórias e tributárias, a cabotagem brasileira poderá atrair novos operadores e disseminar o seu uso, ampliando o rol de clientes.

Apesar das boas perspectivas, a carga conteinerizada é pouco representativa no modal de transportes do país e, apesar do seu crescimento atual acelerado e a manutenção desse crescimento para os próximos anos, não deverá trazer um impacto relevante na matriz modal brasileira, devido a concentração da oferta e demanda dentro da região sudeste, ou seja, realizado em curtas distâncias e alta capilaridade, opção natural do modal rodoviário.

Todavia, caso este mercado consiga, conforme projeção da ABAC, crescer $35,5 \%$ a.a. no próximo quadriênio, conforme detalhado no tópico 5 . E, adicionalmente, para sustentabilidade deste crescimento, ele for acompanhado de investimentos em ampliações de oferta e aumento de produtividade das instalações portuárias brasileiras, para que não haja restrição desse crescimento, pode-se realmente ampliar esse horizonte de crescimento para além dos próximos 4 (quatro) anos seguintes, considerando o potencial de 232 milhões de toneladas, que atualmente estão no modal rodoviário de carga geral inter-regional, conforme estimativas apresentadas no tópico 5.

Além disso, outros desafios precisam ser superados, alguns outros entraves, como o tempo necessário para que o processo de conteinerização possa ser desenvolvido, o que requer tempo, planejamento e, principalmente, custo. Esse não é o problema de cargas normalmente embaladas em sacarias, como arroz, trigo, pois são facilmente conteinerizadas. Há outros tipos de carga, por exemplo, como móveis, que são transportados em grandes caminhões-baú. Essa carga, por exemplo, é de difícil conteinerização, com risco potencial de dano a esse tipo de mercadoria Assim, para a cabotagem competir com o modal rodoviário para o transporte deste tipo de bem, é preciso fazer uma série de estudos para checar a viabilidade de transportar essa carga, no qual são feitos alguns questionamentos, como, por exemplo: onde será estufado o contêiner; no local do cliente; no terminal portuário; como essa carga chega ao porto; como adaptar o contêiner para receber e transportar com segurança as cargas mais frágeis. Portanto, uma venda para a cabotagem é similar a um grande projeto de desenvolvimento comercial. É nisso que os atuais armadores estão atuando e que justifica esse crescimento de 2 (dois) dígitos verificado desde 2012.

Para um entendimento mais completo do panorama atual do transporte de contêiner por cabotagem no Brasil, é importante a visualização da participação relativa dos principais produtos transportados pela marinha mercante brasileira nas suas rotas regulares, apresentadas nas Figuras a seguir, por unidade federativa.

\subsubsection{Mercado - Contêineres - Detalhamento}




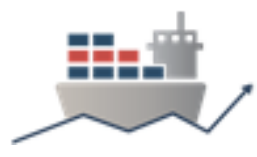

\subsubsection{Contêineres - Arroz}

O principal produto transportado por contêiner ao longo da costa brasileira, incluindo trechos hidroviários é o arroz.

O arroz, pelas suas características, pode ser produzido em grande parte do país nas regiões norte, centro-oeste e o seu principal centro produtor, a região sul do país, com destaque para o estado do Rio Grande do Sul. Entretanto, devido às características climáticas da região nordeste, com déficit hídrico, há uma dificuldade para a introdução do arroz nesta região. No sul do país, o abastecimento do mercado interno é feito na sua maioria por pequenas e médias propriedades.

Segundo o anuário estatístico de transportes 2010-2017 (BRASIL, 2018) o consumo interno da commodity é avaliado em 11,7 milhões de toneladas, considerando a produção total do país em 2017 de 12,3 milhões de toneladas.

Figura 12 - Transporte de arroz, por modal, 2010 - 2017.

Milhões/Ton Transporte da Produção Nacional de Arroz - 2010 - 2017

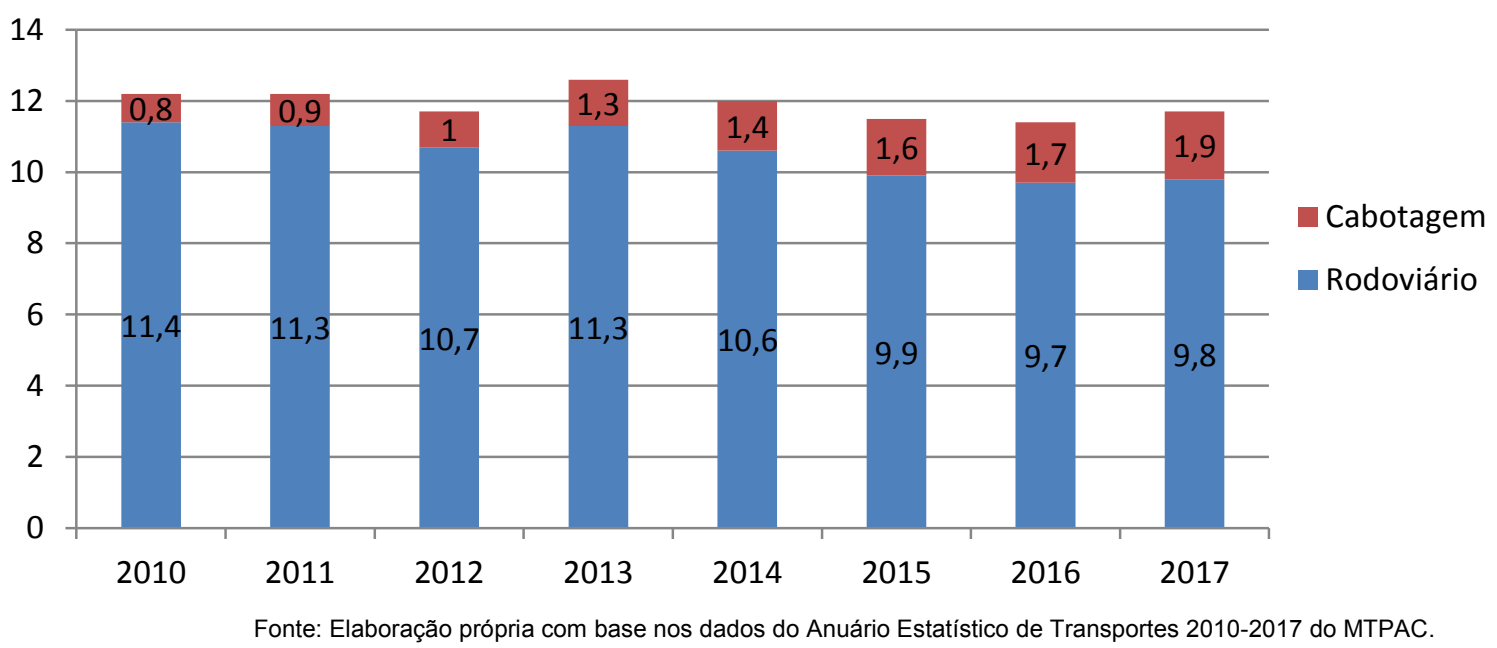

Como se pode observar a partir da análise conjunta do mapa de distribuição interna do arroz, juntamente com os gráficos de origem e destino, conclui-se que, em decorrência da sua produção ser distribuída em três diferentes regiões do território nacional, a maior parte da produção de arroz necessita percorrer curtas distâncias para interligar o seu centro de produção mais próximo com o seu centro de consumo. Em razão dessa variável, mais de $80 \%$ do arroz produzido no país segue pelo modal rodoviário.

Em relação aos aproximadamente $20 \%$ da produção de arroz transportados pela cabotagem, de acordo com nossa análise, esse arroz se origina quase na sua totalidade dos estados do Rio Grande do Sul e de Santa Catarina e destina-se primordialmente para os estados do Ceará e de Pernambuco.

Dessa forma, da análise resultante das Figuras 13 e 14 infere-se que a escolha pelo modal aquaviário foi tomada em razão da distância a ser percorrida, ponderado também pelo volume a ser transportado. Portanto, devido à própria geografia do país, incapaz de produzir a commodity em todo seu território, viabilizou-se o transporte via cabotagem de regiões distantes com aptidões distintas em relação à agricultura, 
VI CIDESPORT/2019

Congresso Internacional

de Desempenho Portuário

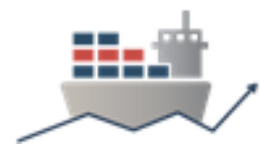

suprindo outra região sem produção local do produto demandado, em decorrência do arroz ser consumido em todo o país.

Figura 13 - Origem das mercadorias transportadas pela cabotagem em 2018, por unidade federativa, com destaque para contêineres - Arroz

Origem - Transporte - Cabotagem - Contêiner - Tonelada Líquida - Estado - 2018

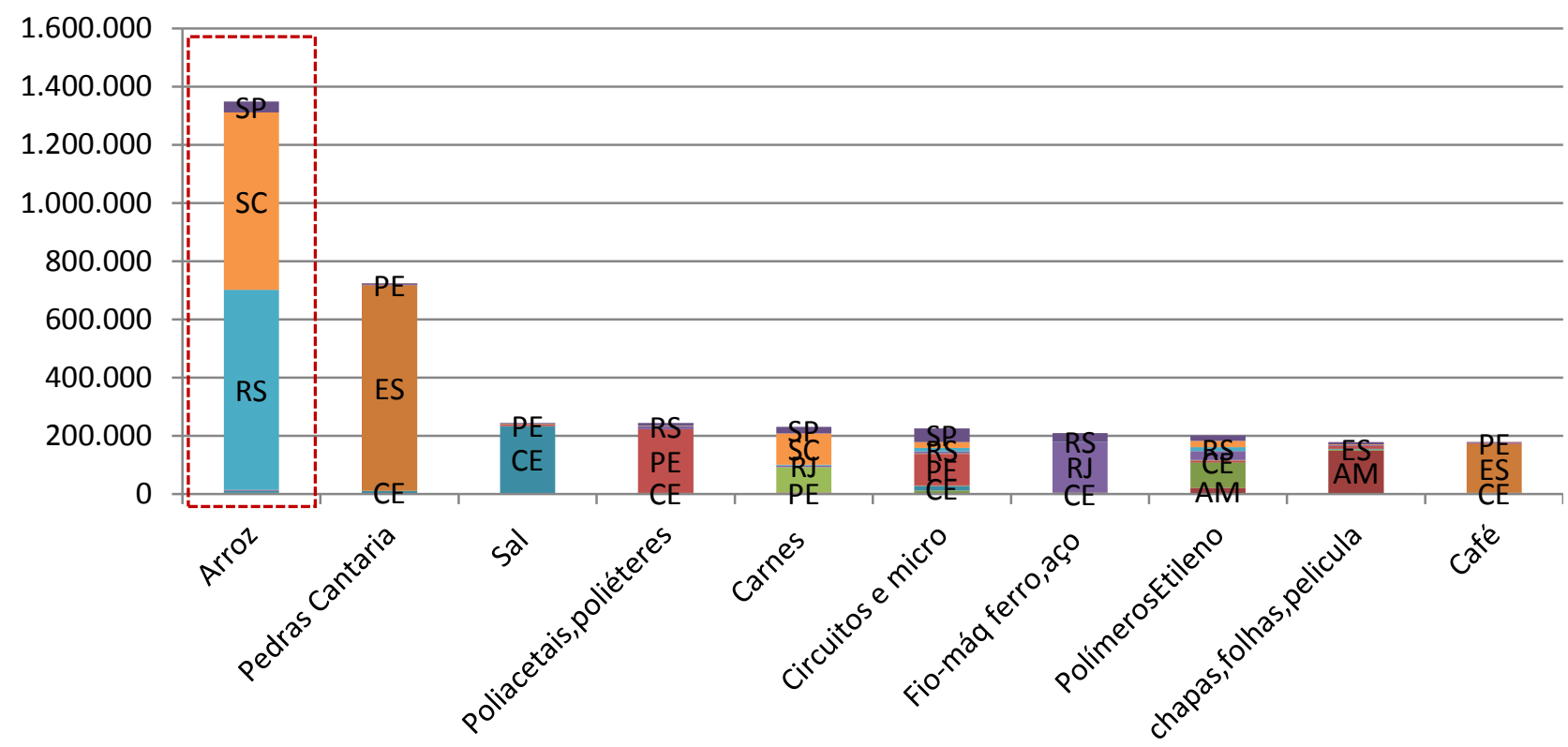

Fonte: Elaboração própria com base nos dados do anuário estatístico de 2018 (ANTAQ, 2018)

Figura 14 - Destino das mercadorias transportadas pela cabotagem em 2018, por unidade federativa, com destaque para contêineres - Arroz

Destino - Transporte - Cabotagem - Contêiner - Tonelada Líquida - Estado - 2018

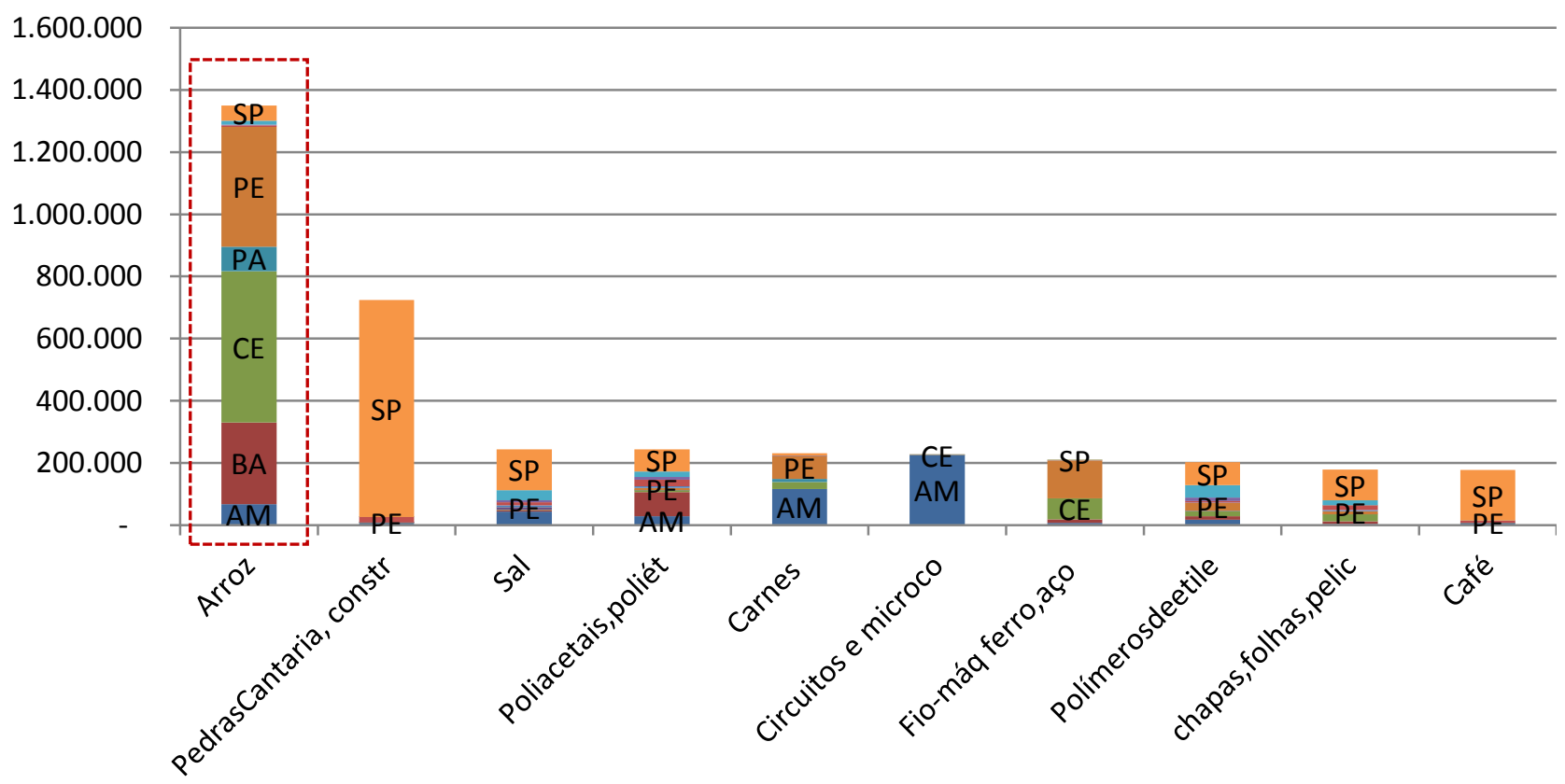




\subsubsection{Contêineres - Pedra de Cantaria}

Segundo Sardou Filho et al.(2013), o Espirito Santo é o principal polo produtor de rochas do Brasil, conforme apresenta a Figura 15, com centenas de beneficiadoras, devido principalmente a fatores ligados à sua própria geografia, infraestrutura ferroportuária, incentivos fiscais e proximidade com os principais centros consumidores, cujo destaque é o estado de São Paulo.

A concentração econômica e populacional de São Paulo, por conseguinte, representa uma maior demanda para as indústrias de construção civil, principal cliente destes produtos, conforme apresentado na Figura 16.

A análise desses fatores de forma conjunta, com as Figuras 15 e 16, caracteriza de forma clara que, neste caso, não foi o fator distância, mas o volume a ser transportado preponderando na sua decisão pelo uso da cabotagem, facilitado pela existência de linhas férreas e Portos públicos e TUPs com rotas regulares na configuração hub-feeder, desde essas instalações portuárias e o Porto de Santos.

Figura 15 - Origem das mercadorias transportadas pela cabotagem em 2018, por unidade federativa, com destaque para contêineres - Pedra de cantaria

Origem - Transporte - Cabotagem - Contêiner - Tonelada Líquida - Estado - 2018

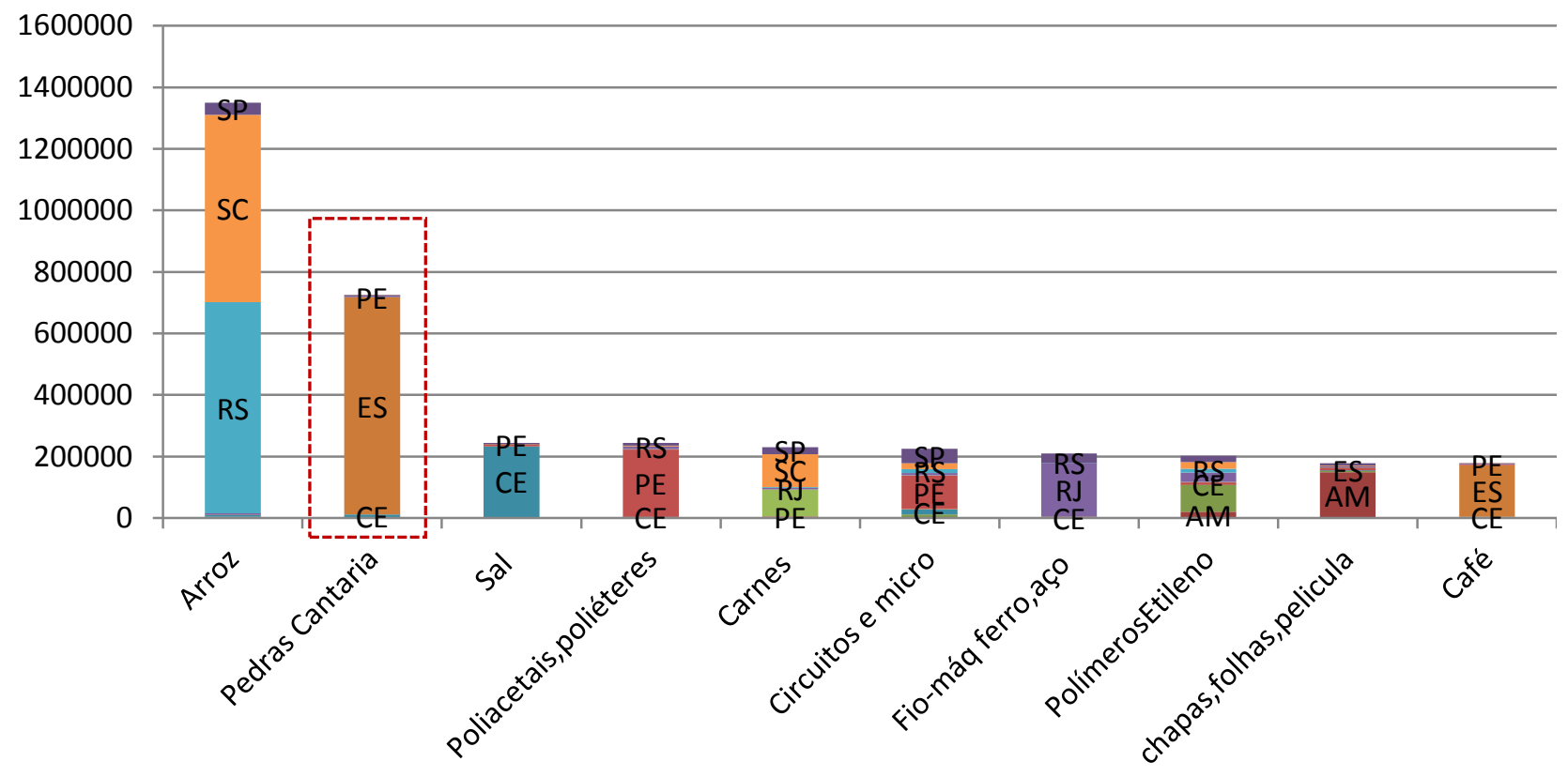

Fonte: Elaboração própria com base nos dados do anuário estatístico de 2018 (ANTAQ, 2018). 
VI CIDESPORT/2019

Congresso Internacional

de Desempenho Portuário

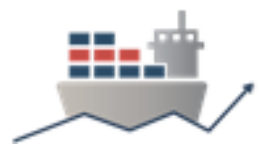

Figura 16 - Destino das mercadorias transportadas pela cabotagem em 2018, por unidade federativa, com destaque para contêineres - Pedra de cantaria

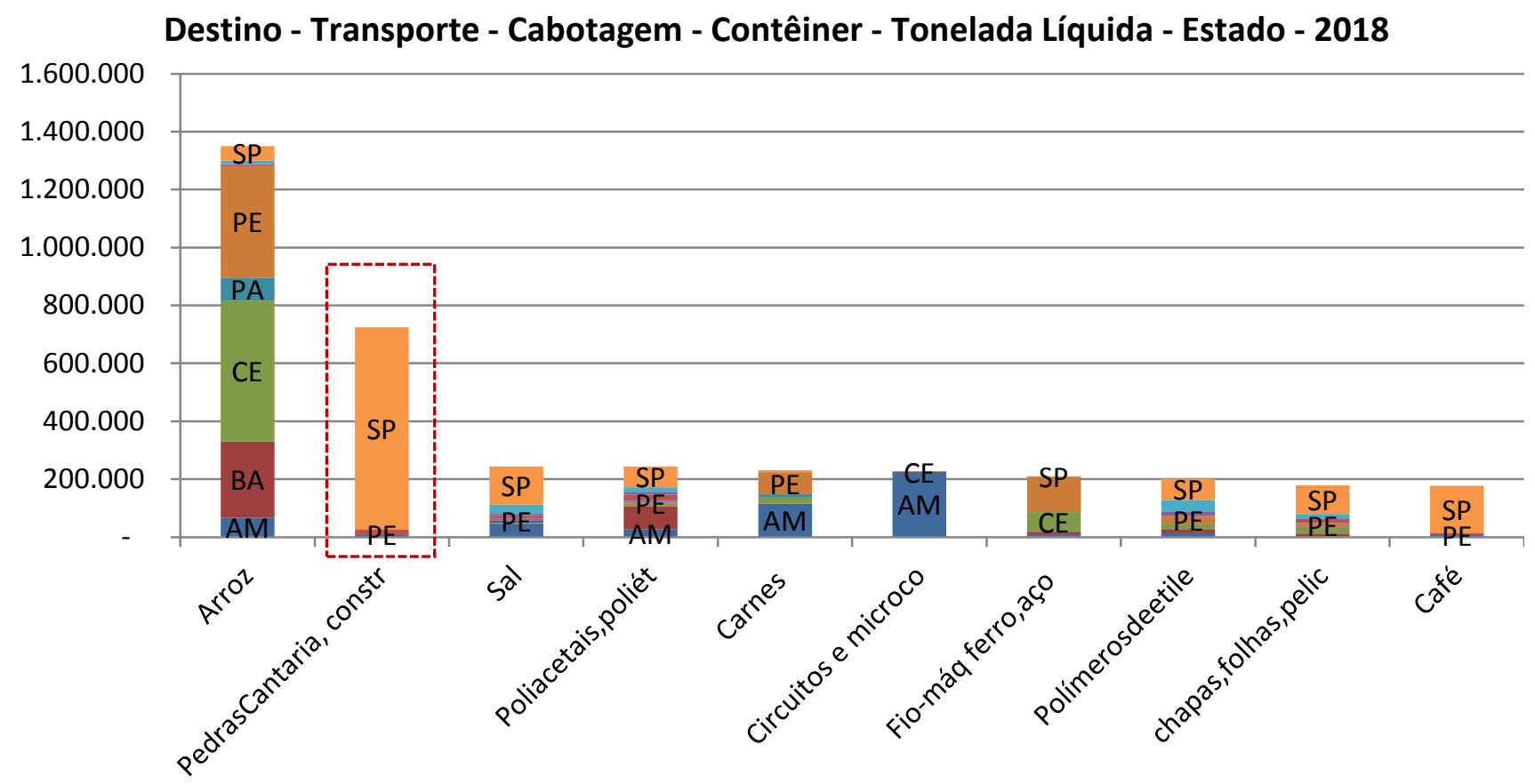

Fonte: Elaboração própria com base nos dados do anuário estatístico de 2018 (ANTAQ, 2018)

\section{ESTIMATIVA DO TRANSPORTE RODOVIÁRIO INTER-REGIONAL DE CARGA GERAL}

Com base na análise do estudo da EPL (EPL, 2015) de origem e destino da carga geral inter-regional, o modal rodoviário representava $87 \%$ de todo o transporte de carga geral do país, considerando todos os modais. A partir deste estudo foi desenvolvida a matriz de origem e destino da carga geral inter-regional, ajustada pelo volume de carga geral transportada em longas distâncias pelo modal rodoviário em 2015, segundo EPL (EPL, 2015). Foram excluídos da matriz, os fluxos de transporte relacionados à região centro-oeste e ao longo curso, excluindo-se também o transporte rodoviário dentro da mesma região geográfica.

Tabela 3 - Matriz de origem e destino - Carga Geral por região

\begin{tabular}{|l|r|l|l|l|}
\hline \multicolumn{5}{|c|}{ Transporte Rodoviário Inter-Regional - Carga Geral } \\
\hline \multicolumn{5}{|c|}{ Matriz O/D - Carga Geral por região (1) } \\
\hline Região & Norte & Nordeste & Sudeste & Sul \\
\hline Norte & & $5.682,0$ & $10.426,4$ & $5.253,3$ \\
\hline Nordeste & $4.927,7$ & & $26.606,9$ & $11.718,3$ \\
\hline Sudeste & $12.020,7$ & $31.514,7$ & & $51.114,4$ \\
\hline Sul & $5.932,2$ & $14.762,6$ & $52.101,6$ & \\
\hline Total & \multicolumn{4}{|c|}{$\mathbf{2 3 2 . 0 6 0 , 8}$} \\
\hline \multicolumn{5}{|c|}{$\begin{array}{l}\text { Fonte: Elaboracăo própria com base nos dados do EPL (2015). } \\
\text { Notas: (1) Em mil toneladas. Ano base 2015. }\end{array}$} \\
\hline
\end{tabular}




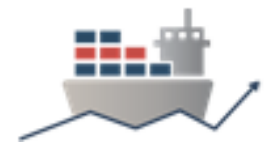

Conservadoramente, devido à dificuldade na obtenção de dados mais detalhados em relação ao fluxo de transporte por produto e por unidade federativa em todos os modais de forma integrada, optou-se por delimitar o potencial de captação pela cabotagem, somente em relação ao modal rodoviário inter-regional de carga geral. Entretanto, é de se supor que com uma maior eficiência em relação a prazo e custos, operações de outros grupos de mercadorias que também estão hoje nas rodovias, em operações de longas distâncias e próximas à costa, também poderiam residualmente migrar para a cabotagem.

Ressalta-se que a estimativa de migração da carga geral inter-regional não é totalmente passível de migração para a cabotagem, devido a fatores diversos, dentre eles: aspectos como a factibilidade e o custo de estufar determinados produtos nos contêineres; prazo reduzido de entrega, típico das entregas expressas; dentre outros fatores que afetam o preço do frete e dificultam a sua substituição pela cabotagem. Todavia, destaca-se que a estimativa apresentada serve como um parâmetro de quanto o mercado da cabotagem de carga geral e contêiner ainda pode crescer, caso sejam superados os fatores que restringem o seu crescimento, principalmente os subsídios ao modal rodoviário.

O mercado de carga conteinerizada e carga geral é o que tem maior potencial de crescimento. Segundo estudo encomendado ao ILOS pela ABAC - Associação Brasileira dos Armadores de Cabotagem, para cada 1 contêiner que está na cabotagem, há 10 contêineres no mercado, que são transportados em caminhão, e passíveis de virem para a cabotagem, sendo que $50 \%$ desses contêineres deverão migrar para a cabotagem nos próximos 5 anos. Com isso, o crescimento da cabotagem de carga conteinerizada/carga geral, que foi de $12,8 \%$ a.a. no período de 2012 a 2018, deverá atingir 35,5\% a.a. no período de 2019 a 2022, segundo o estudo do ILOS.

Tomando como base a projeção da ABAC, de crescimento deste mercado para o próximo quadriênio de $35,5 \%$ a.a., elaborada pelo instituto ILOS. E tendo como ano base 2018, ANTAQ (2018), no qual o volume transportado de carga geral e contêiner foi de 15 milhões de toneladas. Correlacionando estes dois estudos, esse mercado poderia adicionar a cada ano do próximo quadriênio, 5,25 milhões de toneladas, ou seja, $35,5 \%$ de 15 milhões. Segundo o presente estudo, essa migração vai ter origem principalmente no modal rodoviário inter-regional de carga geral, cujo potencial é aferido em 232 milhões de toneladas, segundo EPL (2015).

Portanto, em nossa análise, a projeção da ABAC é perfeitamente factível dentro deste universo de carga geral inter-regional. A adição anual de aproximadamente 5,25 milhões de toneladas/ ano equivale a apenas 2, $2 \%$ de toda carga geral de longa distância que hoje circula por caminhão.

Contudo, cabe aqui destacar, que todo esse potencial de crescimento pode ser restringido pela capacidade/ produtividade das instalações portuárias brasileiras, que atualmente possuem capacidade ociosa, mas que precisariam se desenvolver juntamente com o mercado de cabotagem de carga geral e contêiner, para dar suporte a todo esse potencial de crescimento. Além da desburocratização das atividades relacionadas ao desembaraço das cargas.

Da análise dos dados pesquisados é possível inferir que, a despeito da opção cultural dos produtores brasileiros pelo modal rodoviário, segundo a Confederação Nacional da Agricultura e Pecuária do Brasil (2017?) é notório que o modal rodoviário é a opção menos eficiente no transporte inter-regional em relação a diversos componentes de custo, tais como: custo médio de implantação (estradas); custo 
médio de operação; custo social, relacionado principalmente ao alto registro de acidentes; menor vida útil da via e o seu maior custo de manutenção.

Para melhor ilustrar as vantagens comparativas de custo e emissões dos diferentes modais é apresentada uma comparação entre os modais rodoviários, ferroviários e hidroviários para uma compreensão mais clara dos fatores de decisão na opção do agente econômico pelo uso de um determinado modal em detrimento dos demais:

Tabela 4 - Comparativo entre os modais de transporte brasileiro

\begin{tabular}{|c|c|c|c|c|}
\hline \multicolumn{2}{|l|}{ Fatores/Modal } & Rodoviário & Ferroviário & Hidroviário \\
\hline \multicolumn{2}{|c|}{ Custo médio de implantação (US\$/km) } & 440.000 & 1.400 .000 & 34.000 \\
\hline \multicolumn{2}{|c|}{ Custo médio de operação (US\$/t/km) } & 34 & 21 & 12 \\
\hline \multicolumn{2}{|c|}{ Custos sociais $\left({ }^{*}\right)(\mathrm{US} \$ / 100 \mathrm{t} / \mathrm{km})$} & 3,2 & 0,74 & 0,23 \\
\hline \multicolumn{2}{|c|}{ Consumo de combustível (l/t/1.000 km) } & 96 & 10 & 5 \\
\hline \multirow{4}{*}{$\begin{array}{c}\text { Emissão de poluentes } \\
(\mathrm{Km} / \mathrm{t} / 1.000 \mathrm{~km})\end{array}$} & Hidróxido de carbono & 0,178 & 0,129 & 0,025 \\
\hline & Monóxido de carbono & 0,536 & 0,180 & 0,056 \\
\hline & Oxido de nitrogênio & 2,866 & 0,516 & 0,149 \\
\hline & Dióxido de carbono & 0,164 & 0,0481 & 0,0334 \\
\hline \multicolumn{2}{|c|}{ Vida útil da infraestrutura } & Baixa & Alta & Alta \\
\hline \multicolumn{2}{|c|}{ Custo de manutenção das vias } & Alto & Baixo & Baixo \\
\hline
\end{tabular}

Fonte: Confederação da Agricultura e Pecuária do Brasil - CNA (2017, p.24).

\section{CONCLUSÕES}

A apresentação do panorama geral da cabotagem no Brasil, por meio da exposição da cadeia logística dos principais produtos que atualmente se utilizam do modal aquaviário, tem como objetivo fazer um levantamento dos fatores determinantes na tomada de decisão dos agentes econômicos quando optaram pela cabotagem, caracterizando nessa análise três diferentes mercados de acordo com a lógica econômica que os distinguem dos demais: granéis líquidos, granéis sólidos e carga geral e contêiner.

De maneira geral, esses agentes escolheram a cabotagem principalmente nos casos onde o escoamento da produção envolve longas distâncias e ou grandes volumes, características intrínsecas as cadeias de commodities.

Cabe ressaltar, como resultado da alta concentração em granéis. Das 6 (seis) principais rotas de cabotagem, 4 (quatro) são dedicadas a granéis (petróleo/combustíveis, bauxita, sal e madeira e celulose), uma dedicada à carga geral (bobinas) e uma à carga conteinerizada (Zona Franca Manaus).

A Empresa Brasileira de Navegação para atuar na cabotagem, principalmente de granéis, precisa ter escala para viabilizar a cadeia de commodities, a qual objetiva transportar. Alternativas como a verticalização da cadeia produtiva como nas Industrials Operations, onde a própria empresa atua em todos os elos da cadeia do produto; contratos de longo prazo (take or pay); e, uma maior necessidade de transbordo (hub-feeder) servindo as operações de longo curso, poderia viabilizar mais operações de granéis sólidos, entretanto dependem de uma maior participação do Brasil no mercado internacional e no planejamento em rede de portos e terminais que servem ao país. 


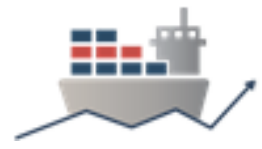

A cabotagem tem dificuldade de se consolidar no Brasil, devido dentre outros fatores, a concentração da produção e do consumo na região Sudeste (menos de 800 $\mathrm{km}$ ), e que devido a curta de distância, permanecerão no modal rodoviário. Outro fator é a ociosidade nos fluxos N/NE $\rightarrow$ SE/S (dificuldade de escala), o que pode afetar a estruturação de novas rotas.

Reitera-se também que o nosso volume de produtos é concentrado em commodities (baixo valor agregado).

Outro fator importante nessa opção se refere à urgência na entrega até o consumidor final, com a preferência pela utilização do modal rodoviário nos casos de armazenamento e redistribuição. Nos casos com lead time curtos, como nas entregas diretas e expressas, mesmo em longas distâncias, os produtores optam pelo modal rodoviário devido a maior percepção de incerteza em relação ao prazo de entrega, devido principalmente a imagem de que o processo de desembaraço das mercadorias nas instalações portuárias ser considerado mais burocrático e demorado. O comércio online, por exemplo, contribui para a necessidade de prazos mais curtos e melhor controle de rastreamento.

O diagnóstico da presente análise é que a cabotagem apresenta potencial de crescimento em dois dos três mercados elencados: Contêineres e Carga Geral e Granéis Líquidos. O primeiro, sobre uma base inicialmente pequena, sendo estimado como potencial de crescimento, a captação gradativa de parte do transporte rodoviário de carga geral de longa distância.

Conclui-se que progressivamente, parte do transporte rodoviário de carga geral inter-regional, estimado em 232 milhões de toneladas, tem potencial para migrar para a cabotagem de carga geral e contêiner, em razão da alta concentração populacional próximo ao litoral e principalmente devido aos seus menores custos. Por fatores diversos relacionados também principalmente a prazo e custos, algumas dessas cargas devem permanecer no modal rodoviário. Deve se ter em conta, que foram transportados pela cabotagem brasileira um total de 163 milhões de toneladas no ano de 2018, havendo um grande potencial de crescimento da cabotagem no Brasil neste mercado, pois apenas $9 \%$ desse total se refere a carga geral e contêiner. Seguindo a projeção $35,5 \%$ a.a. de crescimento a cada ano para o próximo quadriênio, conforme fornecido pela ABAC, a cada ano o mercado de contêineres e carga geral captaria $2,2 \%$ do total de transporte rodoviário de carga geral inter-regional, que para ser sustentável, deve ser acompanhado de investimentos nas instalações portuárias, além de novos processos que desburocratizem o processo de desembaraço das mercadorias.

O mercado de granéis líquidos pode crescer organicamente devido ao aumento da prospecção de Óleo e Gás dos poços maduros hoje existentes nas Bacias de Campos e Santos, mas principalmente em relação as operações do pré-sal, numa resultante das operações logísticas das indústrias que atuam no setor de Óleo e Gás, com destaque para as operações do grupo Petrobrás.

Em relação ao objetivo de pesquisa, com a apresentação do panorama da cabotagem no Brasil, a partir da ótica de origem e destino das cargas e a inferência sobre o seu potencial de transferência para o mercado de cabotagem de carga geral e contêiner, baseado na estimativa do transporte rodoviário de carga geral de longa distância. Cabe ressaltar que devido a indisponibilidade de informações mais detalhadas, em relação a segregação entre transporte regional e inter-regional - por produto, por unidade federativa e por modal, foi delimitado o potencial de captação pela cabotagem, somente em relação ao modal rodoviário inter-regional de carga 
geral, excluindo-se desta base o transporte dentro na mesma região, além de todo fluxo inter-regional da região centro-oeste e do longo curso.

O presente estudo considerou, em relação a apresentação do panorama da origem e destino dos produtos atualmente transportados pela cabotagem, apenas as operações de embarque e desembarque, escopo do anuário estatístico de 2018 (ANTAQ, 2018). Tendo sido mapeado a origem, desde a produção até o seu destino, apenas em relação aos principais produtos transportados pela cabotagem.

Por fim, visando a continuidade da presente pesquisa, é sugerida a exploração de temas correlatos ao objetivo desta pesquisa como: o impacto da ferrovia na cabotagem; estratégia hub-feeder dos armadores e instalações portuárias; impactos da falta de segurança nas estradas, tanto em relação a ocorrência de acidentes, quanto em relação a ocorrência de roubos e furtos; e, o impacto das mudanças climáticas em relação a sustentabilidade ambiental e dificuldades operacionais relacionadas a evento naturais extremos.

\section{REFERÊNCIAS}

ANP. Superintendência de Desenvolvimento e Produção. Boletim de recursos e reservas de petróleo e gás natural 2018. [Rio de Janeiro]: ANP, 2018.

ANTAQ. Anuário ANTAQ. [Brasília, DF, 2018]. Base de dados. Disponível em: http://web.antaq.gov.br/Anuario/.

BERTOLOTO, Rodrigo Ferreira. Eficiência de portos e terminais privativos brasileiros com características distintas. 2010. 70 f. Dissertação (Mestrado em Engenharia de Produção) - Escola de Engenharia, Universidade Federal Fluminense, Niterói, 2010.

Disponível

em:

http://www.dominiopublico.gov.br/pesquisa/DetalheObraForm.do?select action=\&co obra=195441.

BRASIL. Ministério dos Transportes, Portos e Aviação Civil. Anuário estatístico de transportes: 2010 - 2017. Brasília: Ministério dos Transportes, Portos e Aviação Civil, 2018.

Disponível

em:

http://www.infraestrutura.gov.br/images/BIT TESTE/Publica\%C3\%A7oes/anuario es tatistico transportes 2010 2017.pdf.

CONFEDERAÇÃO DA AGRICULTURA E PECUÁRIA DO BRASIL. Infraestrutura logística: desafios para o escoamento dos produtos agropecuários. [Brasília, DF:
CNA,
2017?].
33
Disponível
em:

https://www.cnabrasil.org.br/assets/arquivos/estudos/livrocompleto infraestr

utura logistica-

desafios para o escoamento dos produtos agropecuarios 0.07677600

1515000372.pdf.

EPL. Transporte inter-regional de carga no Brasil: panorama 2015: carregamento com a matriz origem-destino: Plano Nacional de Logística Integrada. Brasília, DF: [s.n.], 2016. 46 slides. Apresentação. 
VI CIDESPORT/2019

Congresso Internacional

de Desempenho Portuário

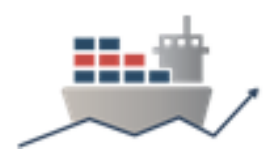

FACHINELLO, Arlei Luiz; NASCIMENTO, Sidnei Pereira. Cabotagem como alternativa para o transporte de carnes da região Sul para o Norte/Nordeste brasileiro: um estudo de caso. Revista de Economia e Sociologia Rural, Piracicaba, v. 46, n. 04, p. 969988, out/dez 2008.

Disponível em: http://dx.doi.org/10.1590/S0103-20032008000400003

GIL, A. C. Métodos e técnicas de pesquisa social. 5.ed. São Paulo: Atlas, 1999.

GONÇALVES, Inácio Marcelo. Estudo logístico para exportação do complexo soja: corredor ferroviário Centro-Leste. 2011. 115 f. Dissertação (Mestrado em Engenharia Civil) - Faculdade de Engenharia Civil, Universidade Federal de Uberlândia, Uberlândia, 2011.

Disponível em: https://repositorio.ufu.br/bitstream/123456789/14158/1/d.pdf

GOULARTI FILHO, Alcides. A trajetória da Marinha Mercante brasileira: administração, regime jurídico e planejamento. Pesquisa \& debate, São Paulo, v. 21, n. 2, p. 247-278, 2010.

Disponível em: https://revistas.pucsp.br/rpe/article/view/7397/5370. Acesso em:

ILOS. Panorama ILOS: custos logísticos no Brasil. [s.I.]: ILOS, 2016.

RESSURGIMENTO da indústria naval no Brasil: (2000-2013). Brasília: Ipea, 2014. $480 \mathrm{p}$.

Disponível

em:

http://www.ipea.gov.br/portal/images/stories/PDFs/livros/livros/livro ressurg da ind naval.pdf.

RODRIGUES, Jondison Cardoso; RODRIGUES, Jovenildo Cardoso; CASTRO, Edna Maria Ramos de. Transporte hidroviário, portos e terminais interiores na Amazônia brasileira: uma análise sobre seus papéis na política pública territorial. Geo UERJ, Rio de Janeiro, v. 1, n. 25, p.115-137, 1 sem. de 2014.

Disponível em: https://doi.org/10.12957/geouerj.2014.8197

SARDOU FILHO, Rubens et al. Atlas de rochas ornamentais do estado do Espírito Santo. Brasília, DF: CPRM, 2013. 349 p. Disponível em: http://rigeo.cprm.gov.br/jspui/handle/doc/17787

SILVEIRA JÚNIOR, Aldery. Cabotagem brasileira: uma abordagem multicritério. Curitiba: Appris, 2018. 164 p. ISBN 9788547318314. 